\title{
HISTORICAL AND ENVIRONMENTAL DISTRIBUTION OF ICHTHYOFAUNA IN THE TROPICAL WETLAND OF PANTANOS DE CENTLA, SOUTHERN GULF OF MEXICO
}

\author{
Alberto MACOSSAY-CORTEZ ${ }^{1}$, Alberto J. SÁNCHEZ ${ }^{1 *}$, Rosa FLORIDO ${ }^{1}$, \\ Leticia HUIDOBRO ${ }^{2}$, and Hugo MONTALVO-URGEL ${ }^{1}$ \\ ${ }^{1}$ Laboratorio de Hidrobiología, Diagnóstico y Manejo de Humedales Tropicales, \\ División Académica de Ciencias Biológicas, UJAT, México \\ ${ }^{2}$ Colección Nacional de Peces, Instituto de Biología, UNAM, México
}

\begin{abstract}
Macossay-Cortez A., Sánchez A.J., Florido R., Huidobro L., Montalvo-Urgel H. 2011. Historical and environmental distribution of ichthyofauna in the tropical wetland of Pantanos de Centla, southern Gulf of Mexico. Acta Ichthyol. Piscat. 41 (3): 229-245.
\end{abstract}

\begin{abstract}
Background. Thirty species were previously recorded for unstructured habitats (unvegetated soft substrates: USS) in Pantanos de Centla. However, a lack of information on the tropical ichthyofauna of the structured habitats such as marginal vegetation (MV), submerged macrophytes (SM) and coarse woody debris (CWD) emphasizes the importance of the aim of this paper that is the updating the records of the species distributed in these habitats, as they have been frequently reported as high biodiversity sites that are currently threatened by anthropogenic activities.

Materials and methods. Sampling was carried out in 30 shallow sites, each with unstructured habitats and the three structured habitats, in Pantanos de Centla, a Ramsar wetland, over a period of three years. Fish were collected with a dip net, a drop net and a Renfro beam net.

Results. A total of 6506 fish of 37 genera and 44 species were collected. Eleven species are new records for Pantanos de Centla, and the scientific name of 11 species was updated. The Poeciliidae and Cichlidae families are dominant with 10 and 13 species, respectively. Nine species of the genus Cichlasoma sensu lato were placed in six genera. Three species are new records for the Usumacinta Province. Ctenogobius claytoni, Gobionellus oceanicus, and Rhamdia quelen proved to be synonyms. Of all species, $84 \%$ were collected from USS, however, the number of species distributed in USS, MV, and SM was similar $\left(\mathrm{CC}_{\mathrm{j}} 0.4736-0.5813\right)$.

Conclusion. Most of the species that were added to the previously recorded species list of Pantanos de Centla, inhabit structured habitats. This confirms the importance of including these habitats in surveys aimed at generating checklists, and of analysing the distribution of fish species in shallow tropical ecosystems.
\end{abstract}

Keywords: Ichthyofauna, submerged macrophytes, coarse woody debris, marginal vegetation, unvegetated soft substrates, diversity, tropical, wetland

\section{INTRODUCTION}

Freshwater ecosystems represent $0.8 \%$ of the world's surface and harbour $6 \%$ of the total diversity. However, the list of freshwater species is still incomplete and the rate of species loss is surely greater than has been estimated, particularly in tropical ecosystems (Revenga et al. 2005, Dudgeon et al. 2006). Approximately 2700 fish species have been recorded in Mexico (Contreras-Balderas et al. 2003, Espinosa-Pérez et al. 2008), and are found mostly in specialized publications, museum records, and collections (Miller et al. 2005). Of this total, only 495 are freshwater species (Miller et al. 2005), in marked contrast with the 662 native freshwater species that have been recorded exclusively for the southeastern USA (Warren et al. 2000).
Distributions associated with a particular habitat have been widely recorded for freshwater and estuarine fauna (Heck and Crowder 1991, Gilmore 1995, Hines and Ruiz 1995, Moksnes et al. 1997, Sánchez and Raz-Guzman 1997, Rozas and Minello 2006, Montalvo-Urgel et al. 2010). Freshwater fish are no exception, as they are markedly associated with specific habitats (Pelicice and Agostinho 2006, Sammons and Maceina 2006, Yamazaki et al. 2006). This type of distribution associated with a particular habitat, especially structured habitats, is subject to an increased risk caused by anthropogenic impact because habitat loss is one of the most important threats to biodiversity conservation (Warren et al. 2000, Dudgeon et al. 2006) due to the relative value of "in sensu" habitats, as stated by Minello and Zimmerman (1991).

\footnotetext{
* Correspondence: Dr. Alberto J. Sánchez, Laboratorio de Hidrobiología, Diagnóstico y Manejo de Humedales Tropicales, División Académica de Ciencias Biológicas, UJAT. km 0.5 carretera Villahermosa-Cárdenas, Villahermosa 86039 Tabasco, México, phone: (52) 993 337 9611, fax: (52) 993 354 4308, e-mail:alberthoj.sanchez@gmail.com.
} 
The drastic reduction or disappearance of areas with submerged macrophytes and marginal vegetation, the prevalence of eutrophic and hypereutrophic conditions, and changes in the flood pulses in the Biosphere Reserve of Pantanos de Centla (BRPC) (Sánchez et al. 2007, RuízCarrera and Sánchez 2008) have been associated with fisheries over-exploitation, changes in the use of the land, inputs of cattle and human feces generated by the lack of municipal services, and the frequent and improvised construction of canals and dams above the high Grijalva watershed (Sánchez et al. 2007, Guerra and Ochoa 2008, Oswald-Spring 2008). This pressure on fish and habitats emphasizes the importance of updating the list of 30 fish species recorded by Reséndez-Medina and Salvadores (2000), who sampled only in unvegetated soft substrates (USS) with one sampling gear. The fact that these previous records were restricted to USS excluded species specifically distributed in other habitats, such as the three structured habitats of submerged macrophytes, coarse woody debris and marginal vegetation. Added to this, these three habitats have suffered a drastic reduction in cover area (Sánchez et al. 2007, Guerra and Ochoa 2008). This reduction is magnified in the case of submerged macrophytes and coarse woody debris that cover less than $1 \%$ of the total bottom area in the aquatic ecosystem (Sánchez et al. 2007). In spite of the anthropogenic pressures and habitat losses recorded in the BRPC, the number of fish species is expected to increase with the inclusion of the three structured habitats and other sampling gears. In addition, the name and number of the species may vary following the recent changes in the taxonomic identities of fish (Miller et al. 2005, Marceniuk and Menezes 2007, Marceniuk and Betancur-R. 2008, LópezFernández et al. 2010, McMahan et al. 2010). The updated fish catalogue provides a base line from which to develop future comparative studies in the Usumacinta Province, and emphasizes the necessity to include structured habitats in monitoring programmes to evaluate fish biodiversity in wetlands.

\section{MATERIALS AND METHODS}

Study area. The BRPC is located in the low basin of the rivers Usumacinta-Grijalva, on the coastal plain of the southern Gulf of Mexico (lat 17 $57^{\prime} 53^{\prime \prime}-18^{\circ} 39^{\prime} 03^{\prime \prime} \mathrm{N}$, long $\left.92^{\circ} 06^{\prime} 39^{\prime \prime}-92^{\circ} 47^{\prime} 58^{\prime \prime} \mathrm{W}\right)$. The annual volume of water provided by both rivers $\left(115715\right.$ million $\left.\mathrm{m}^{3}\right)$ is second in the Gulf of Mexico after the Mississippi River (Velázquez 1994, Wetzel 2001).

The emergent macrophytes, arboreal hydrophytes and freely floating macrophytes confined to the margins of the aquatic ecosystems were grouped in this study as marginal vegetation. Among the emergent macrophytes, the dominant species include Thalia geniculata (bent alligator-flag), Typha domingensis (southern cattail), Haematoxylon campechianum (tinto), Rhizophora mangle (red mangrove), Bucida buceras (gregorywood), Pachira aquatica (pachira), Tabebuia rosea (pink trumpet-tree), and the fallow associations (Guadarrama and Ortíz 2000). The arboreal hydrophytes are the main source of coarse woody debris and are found in the aquatic ecosystems. Another important group of marginal vegetation in the Reserve is that of the grasslands (Guadarrama and Ortíz 2000). The water hyacinth, Eichhornia crassipes, and the water lettuce, Pistia stratiotes, are the dominant freely floating macrophytes (Guadarrama and Ortíz 2000). The dominant submerged macrophytes are represented in the lagoons by the wild celery, Vallisneria americana, and the fanwort sargassum, Cabomba palaeformis.

The choice of the 30 sampled localities was based on the spatial distribution, as presence-absence, of the three structured habitats (marginal vegetation, submerged macrophytes, coarse woody debris), considering that unvegetated soft substrates are present throughout the aquatic ecosystem of the BRPC (Table 1) (Sánchez et al. 2007). Of the structured habitats, submerged vegetation and coarse woody debris each occupy less than $1 \%$ of the substrate, while marginal vegetation covers approximately $83 \%$ of the margins of the Reserve (Sánchez et al. 2007). Although all sampling sites included marginal vegetation, the areas with a dominance of exotic grassland were excluded from the study. The three structured habitats harbour a high faunistic diversity in other wetlands (Minello and Zimmerman 1991, Pelicice and Agostinho 2006, Rozas and Minello 2006, Cetra and Petrere 2007, Genkai-Kato 2007, Rozas and Minello 2010). A second criterium for the selection of sampling sites considered their location in the hydrologic basin and sub-basins (Table 1). The influence of the tidal currents, detected by salinity values (Practical Salinity Scale: PSS), was restricted to values below PSS 3 (Sánchez et al. 2007). The Usumacinta (U), Grijalva (G), and Tres Brazos (TB) sub-basins were re-named following the description of Velázquez (1994).

Sampling methods. Sampling was carried out from 2000 to 2010 during the minimum (April-March) and maximum (October-November) flooding seasons. Different sampling nets and methods were used to collect fish, considering the physical structure of each habitat. Dip nets with an area of $0.117 \mathrm{~m}^{2}$ and $1-\mathrm{mm}$ mesh size were operated for $10 \mathrm{~min}$ in the areas of marginal vegetation. A drop net $\left(0.36 \mathrm{~m}^{2}\right)$ was used over the submerged macrophytes. A Renfro beam net with a $1.8-\mathrm{m}$ mouth and 0.8-mm mesh size (Renfro 1962) was used on the unvegetated soft substrates. The coarse woody debris was extracted manually and the fish were collected from the surface and from the galleries and holes in the trunks.

The identification of the fish species was based on the criteria established by Rauchenberger (1989), CastroAguirre et al. (1999), Carpenter (2002a, b), Miller et al. (2005), and Marceniuk and Betancur-R. (2008). The species are listed in the phylogenetic order proposed by Nelson (2006), and the updated species names were taken from the electronic FishBase web page (Froese and Pauly 2011).

The catalogue includes for each species the scientific name, the geographic distribution with emphasis on the basins of the rivers Tonalá, Grijalva, and Usumacinta, the local distribution in the BRPC, the habitat and notes. 
The material examined includes the total number collect- et al. (2007), Pérez-León and Schmitter-Soto (2007), ed. This is included to indicate qualitative trends and not Soria-Barreto and Rodiles-Hernández (2008), Lópezto carry out a quantitative analysis, considering that non- López et al. (2009), Castillo-Domínguez et al. 2011, and comparative sampling methods were used. The average Froese and Pauly (2011). The average temperature $\left({ }^{\circ} \mathrm{C}\right)$ and the range of total length (TL) are in $\mathrm{cm}$. The geo- and PSS salinity for the locality of each species are graphic distribution of the species included in this list included in the local distribution. The habitats are abbreagrees with the records published by Reséndez-Medina viated as marginal vegetation (MV), submerged macro(1980, 1981), Lozano-Vilano and Contreras-Balderas phytes (SM), coarse woody debris (CWD) and unvegetat(1987), Gaspar-Dillanes (1996), Chávez et al. (1989), ed soft substrates (USS). The notes include distinctive taxReséndez-Medina and Kobelkowsky-Díaz (1991), Ayala- onomic characteristics to compare with similar congeneric Pérez et al. (1998), Espinosa-Pérez et al. (1998), species recorded for the Grijalva-Usumacinta Division Schmitter-Soto (1998), Castro-Aguirre et al. (1999), (Minckley et al. 2005). The state of conservation considerReséndez-Medina and Salvadores (2000), Avilés-Torres ing the official Mexican Norm (Anonymous 2010a) and et al. (2001), Ayala-Pérez et al. (2003), Darrin et al. the Red List of Threatened Species (Anonymous 2011a) (2004), Chávez-López et al. (2005), Corona (2005), are mentioned in the notes as well.

Espinosa-Pérez and Daza-Zepeda (2005), Miller et al. The distribution of the species was analysed through (2005), Rodiles-Hernández et al. (2005), Lozano-Vilano a similarity analysis, which was based on comparative

Location of the sites with respect to the hydrologic sub-basins defined by Velázquez (1994)

\begin{tabular}{|c|c|c|c|c|c|c|c|c|}
\hline \multirow{2}{*}{ Locality } & \multirow{2}{*}{$\begin{array}{c}\text { Geographical } \\
\text { position (UTM) }\end{array}$} & \multirow{2}{*}{$\begin{array}{l}\text { Basin or } \\
\text { sub-basin }\end{array}$} & \multicolumn{4}{|c|}{ Habitat } & \multirow{2}{*}{$\mathrm{T}$} & \multirow{2}{*}{$\mathrm{S}$} \\
\hline & & & MV & SV & CWD & USS & & \\
\hline Ribera Alta ${ }^{1}$ River & $547995-2028872$ & $\mathrm{U}$ & + & & & & 28.3 & 0.4 \\
\hline San Pedrito Lagoon & $542550-2030632$ & $\mathrm{U}$ & + & + & + & + & 28.9 & 1.3 \\
\hline Punteada Lagoon & $561812-2030260$ & $\mathrm{U}$ & + & & + & + & 28.4 & 0.6 \\
\hline El Guanal Lagoon & $558711-2022995$ & $\mathrm{U}$ & + & + & + & + & 28.3 & 0.9 \\
\hline San Isidro Lagoon & $555330-2035112$ & $\mathrm{U}$ & + & & & + & 28.3 & 0.4 \\
\hline El Coco Lagoon & $532455-2043530$ & TB & + & & + & + & 29.1 & 0.8 \\
\hline Frontera bridge $^{1}$ & $536851-2046906$ & TB & + & & & & 28.1 & 0.6 \\
\hline San Pedro y San Pablo bridge ${ }^{1}$ & $556200-2061000$ & $\mathrm{U}$ & + & & & & 28.9 & 2.0 \\
\hline El Cometa Lagoon & $558134-2041912$ & $\mathrm{U}$ & + & & + & + & 28.7 & 2.5 \\
\hline Drain Narváez Norte & $582532-2039796$ & $\mathrm{U}$ & + & & & & 28.1 & 0.7 \\
\hline Narváez Lagoon & $581337-2036132$ & $\mathrm{U}$ & + & & & & 29.6 & 1.0 \\
\hline Drain Narváez Sur & $580726-2028665$ & $\mathrm{U}$ & + & & & & 29.8 & 1.1 \\
\hline El Viento Lagoon & $536135-2015450$ & TB & + & & & + & 29.9 & 0.2 \\
\hline Concepción Lagoon & $580726-2028665$ & $\mathrm{G}$ & + & & & + & 28.6 & 0.5 \\
\hline Larga Lagoon & $541622-2012153$ & $\mathrm{G}$ & + & & & + & 28.7 & 0.2 \\
\hline Grijalva Centro River & $534754-2017974$ & TB & + & & & & 24.1 & 0.2 \\
\hline Los Ídolos Lagoon & $538880-2021224$ & TB & + & & + & + & 28.9 & 0.5 \\
\hline River Bitzal 7th Section & $554772-1997502$ & G & + & & & & 28.6 & 0.3 \\
\hline El Tintal Lagoon & $541326-1999982$ & $\mathrm{G}$ & + & & & + & 27.3 & 0.4 \\
\hline River Bitzal 5th Section & $559779-1997322$ & G & + & & & & 28.7 & 0.2 \\
\hline Landeros Lagoon & $559537-2002719$ & G & + & & & + & 29.9 & 0.8 \\
\hline Sargazal Lagoon & $567113-2003620$ & G & + & & + & + & 29.6 & 0.3 \\
\hline El Loncho Lagoon & $565334-2001124$ & G & + & & & + & 29.7 & 0.5 \\
\hline Chichicastle Lagoon & $561616-2013710$ & $\mathrm{U}$ & + & + & & + & 28.7 & 0.3 \\
\hline El Sauzo Lagoon & $567332-2013974$ & $\mathrm{U}$ & + & + & & + & 29.2 & 0.3 \\
\hline San Isidro El Jobo Lagoon & $576193-2008687$ & $\mathrm{U}$ & + & & & + & 28.3 & 0.3 \\
\hline Cantemoc Lagoon & $569920-2015809$ & $\mathrm{U}$ & + & & & + & 28.7 & 0.7 \\
\hline San Román channel & $535300-2045675$ & TB & + & & & & 26.7 & 0.3 \\
\hline Arroyo Punteada & $560135-2030981$ & $\mathrm{U}$ & + & & & & 28.0 & 0.5 \\
\hline Elpídio Sánchez ${ }^{1}$ River & $581064-2017940$ & $\mathrm{U}$ & + & & & & 28.5 & 1.0 \\
\hline
\end{tabular}

${ }^{1}$ Usumacinta River, $\mathrm{U}=$ Usumacinta, $\mathrm{G}=$ Grijalva, $\mathrm{TB}=$ Tres Brazos, $\mathrm{T}=$ annual average temperature $\left[{ }^{\circ} \mathrm{C}\right], \mathrm{S}=$ annual average salinity (PSS); Habitats: $\mathrm{MV}=$ marginal vegetation, $\mathrm{SM}=$ submerged macrophytes, $\mathrm{CWD}=$ coarse woody debris, USS = unvegetated soft substrates. 
tables of species presence and absence using the Jaccard coefficient (Brower and Zar 1981) for the four types of sampled habitats. The biological material was deposited in the National Fish Collection of the Instituto de Biología, UNAM, Mexico, under reference numbers CNPE-IBUNAM 16673 to CNPE-IBUNAM 16728.

Fish sampling were carried out according the General Law to Fish and Aquaculture Sustainables (Anonymous 2007).

\section{RESULTS}

A total of 6506 freshwater, estuarine, and marine fish were collected, of which 4286 specimens were identified to species level, representing 19 families, 37 genera, and 44 species. The 2220 unidentified fish included larvae of the families Loricariidae, Atherinopsidae, Poeciliidae, Gerreidae, Cichlidae, Eleotridae, and Gobiidae. The fish were classified ecologically as 32 freshwater-, four estuarine-, and eight marine species. The best represented families of freshwater fish were the Poeciliidae and Cichlidae with 10 and 13 species respectively. Eleven species, Rhamdia quelen (Quoy et Gaimard, 1824), Amphilophus robertsoni (Regan, 1905), Parachromis friedrichsthalii (Heckel, 1840), Paraneetroplus synspilus (Hubbs, 1935), Rocio octofasciata (Regan, 1903), Theraps heterospilus (Hubbs, 1936), Thorichthys helleri (Steindachner, 1864), T. meeki Brind, 1918, T. pasionis (Rivas, 1962), Ctenogobius claytonii (Meek, 1902), and Gobionellus oceanicus (Pallas, 1770) were reassigned in this study. Eleven species represented new records for the BRPC (Table 2).

The greatest similarity levels were obtained for the $\mathrm{MV}$ and USS $\left(\mathrm{CC}_{\mathrm{j}}=0.5813\right)$, followed by the MV and $\operatorname{SM}\left(\mathrm{CC}_{\mathrm{j}}=0.4857\right)$, and the SM and USS $\left(\mathrm{CC}_{\mathrm{j}}=0.4736\right)$. The lowest similarity levels were recorded between the CWD and each of the other three habitats $\left(\mathrm{CC}_{\mathrm{j}}=0.0909\right.$, $\mathrm{CC}_{\mathrm{j}}=0.0909, \mathrm{CC}_{\mathrm{j}}=0.081$, respectively). Species collected in the four habitats were Paraneetroplus synspilus (Hubbs, 1935) and Dormitator maculatus (Bloch, 1792). In contrast, the poeciliids Belonesox belizanus Kner, 1860, Heterandria bimaculata (Heckel, 1848), Poecilia petenensis Günther, 1866, Xiphophorus maculatus (Günther, 1866), and Cichlasoma pearsei (Hubbs, 1936) were restricted to MV, and Brycon guatemalensis Regan, 1908, Cathorops aguadulce (Meek, 1904), Diapterus auratus Ranzani, 1842, Bairdiella chrysoura (L.), Oreochromis niloticus (L.), Citharichthys spilopterus Günther, 1862, and Achirus lineatus (L.) were found only on USS. All poeciliids (10 species) and eleotrids (three species) were collected in structured habitats (MV, SM, CWD). The other $77 \%$ of the species were distributed in two or three of the sampled habitats (Table 2).

\section{CLASS ACTINOPTERYGII ORDER CLUPEIFORMES FAMILY ENGRAULIDAE Anchoa parva (Meek et Hildebrand, 1923)}

Material: Number of specimens: 109; TL: 1.7-3.5 cm; TL average: $2.5 \mathrm{~cm}$.

Distribution: From the N and NE coast of Yucatán to Venezuela, including Cuba, Jamaica, and the Antilles along the Atlantic.
Table 2

Distribution of freshwater primary ${ }^{1}$, freshwater secondary ${ }^{2}$, estuarine ${ }^{3}$, marine ${ }^{4}$, and vicarious ${ }^{5}$ fish with respect to the four habitats in the Biosphere Reserve of Pantanos de Centla

\begin{tabular}{|c|c|c|c|}
\hline Species & MV & SM & USS CWD \\
\hline Anchoa parva ${ }^{4}(\mathrm{a}, \mathrm{b})$ & & 107 & 2 \\
\hline Dorosoma petenense $e^{5}$ & & 25 & 39 \\
\hline Astyanax aeneus ${ }^{1}$ & 156 & 169 & 174 \\
\hline Brycon guatemalensis ${ }^{1(b)}$ & & & 1 \\
\hline Hyphessobrycon compressus $^{1}$ & 54 & 66 & 89 \\
\hline Cathorops aguadulce 4 & & & 1 \\
\hline Rhamdia quelen ${ }^{1}$ & 1 & 1 & 5 \\
\hline Atherinella alvarezi $i^{5}$ & 30 & 31 & 10 \\
\hline Hyporhamphus mexicanus ${ }^{5}$ & 5 & & 1 \\
\hline Rivulus tenuis ${ }^{1}$ & 9 & & 4 \\
\hline Belonesox belizanus $^{2}$ & 5 & & \\
\hline Carlhubbsia kidderi ${ }^{2}$ & 12 & 785 & 24 \\
\hline Gambusia sexradiata $^{2}$ & 609 & & 17 \\
\hline G. yucatana ${ }^{2}$ & 209 & 30 & 5 \\
\hline Heterandria bimaculata ${ }^{2}$ & 2 & & \\
\hline Heterophallus aff. rachovii ${ }^{2(\mathrm{a}, \mathrm{b})}$ & 226 & 8 & 11 \\
\hline Phallichthys fairweatheri ${ }^{2}$ & 122 & & 4 \\
\hline Poecilia mexicana ${ }^{2}$ & 20 & & 3 \\
\hline
\end{tabular}

P. petenensis
Xiphophorus maculatus

Microphis brachyurus $^{4}$ (b)

Ophisternon aenigmaticum ${ }^{1(b)}$

Diapterus auratus ${ }^{4(b)}$

Bairdiella chrysoura ${ }^{4}$ (b)

Amphilophus robertsoni ${ }^{2}$

Cichlasoma pearsei ${ }^{2}$

C. salvini ${ }^{2}$

C. urophthalmum ${ }^{2}$

Oreochromis niloticus ${ }^{2}$

Parachromis friedrichsthalii ${ }^{2}$

Paraneetroplus synspilus ${ }^{2}$

Petenia splendida ${ }^{2}$

Rocio octofasciata ${ }^{2}$

Theraps heterospilus ${ }^{2}$

Thorichthys helleri ${ }^{2}$

T. meeki $i^{2}$

T. pasionis $^{2}$

Dormitator maculatus ${ }^{3}$

Eleotris amblyopsis ${ }^{3}$

Gobiomorus dormitor $^{3}$

Ctenogobius claytonit $^{3(\mathrm{a}, \mathrm{b})}$

Gobionellus oceanicus $^{4}$ (b)

Citharichthys spilopterus ${ }^{4}$ (b)

Achirus lineatus $^{4(\mathrm{~b})}$

\begin{tabular}{lllll}
\hline No. & 33 & 20 & 36 & 4 \\
\hline
\end{tabular}

a new records for the Usumacinta-Grijalva Division, ${ }^{\mathrm{b}}$ new records for Pantanos de Centla; No. = number of species per type of habitat; The number of each fish species is included by habitat; Habitats: $\mathrm{MV}=$ marginal vegetation, $\mathrm{SM}=$ submerged macrophytes, USS = unvegetated soft substrates, $\mathrm{CWD}=$ coarse woody debris. 
Local distribution: San Pedrito and El Coco lagoons in $29^{\circ} \mathrm{C}$ and PSS 1 , on average.

Habitat: 98\% was collected from SM (Vallisneria americana) and $2 \%$ from USS.

Notes: This species differs from $A$. mitchilli (Valenciennes, 1848) as it is higher, and it has more gill rakers (24-27) and fewer anal rays (21-25) (SchmitterSoto 1998, Castro-Aguirre et al. 1999, Miller et al. 2005). This is the first record of this species for the limnetic ecosystems of the Usumacinta Province and the BRPC, as it was previously recorded for shallow estuaries in Yucatán and Quintana Roo, Mexico, and for freshwater ecosystems in Guatemala and Panama (Castro-Aguirre et al. 1999).

\section{FAMILY CLUPEIDAE}

Dorosoma petenense (Günther, 1867)

Material: Number of specimens: 64; TL: $1.5-6.5 \mathrm{~cm}$; TL average: $3.7 \mathrm{~cm}$.

Distribution: Basin of the Mississippi River, from Ohio to southern Texas and Florida, USA. In Mexico, on the coastal plain of the Gulf of Mexico from Tamaulipas, basins of the rivers Grijalva and Usumacinta in Chiapas and Tabasco, south to the Yucatán peninsula. NW Guatemala and Belize (Belize River) along the Atlantic.

Local distribution: El Sauzo, El Guanal, Concepción, El Viento, Cantemoc, San Isidro and San Isidro-El Jobo lagoons in $28.8^{\circ} \mathrm{C}$ and PSS 0.5 , on average.

Habitat: 61\% was collected from SM and 39\% from USS. Notes: This species differs from $D$. anale Meek, 1904 by having a terminal mouth, a maxilla without a notch on the ventral border and a longer dorsal filamentous ray (Schmitter-Soto 1998, Miller et al. 2005). D. anale was not collected in this study, but was reported for the area by Reséndez-Medina and Salvadores (2000) and for the same ichthyofaunistic province by Minckley et al. (2005).

\section{ORDER CHARACIFORMES \\ FAMILY CHARACIDAE \\ Astyanax aeneus (Günther, 1860)}

Material: Number of specimens: 499; TL: 1.3-7.1 cm; TL average: $3.5 \mathrm{~cm}$.

Distribution: From the Papaloapan River, Tonalá River basin, Grijalva River basin in Chiapas and Tabasco, Mexico south to Costa Rica along the Atlantic; From the Armería River, Mexico south to Colombia along the Pacific.

Local distribution: The Narváez Norte and Narváez Sur drains, the lagoons Cantemoc, Chichicastle, Concepción, El Coco, El Cometa, El Guanal, El Loncho, El Sauzo, El Tintal, El Viento, Landeros, Larga, Los Ídolos, Narváez, Punteada, San Isidro, San Isidro El Jobo, San Pedrito, Sargazal, Puente Frontera, the 5th and 7th section of the Bitzal River, Grijalva Centro River, and the 1st section of the Ribera Alta River (Usumacinta River) in $28.6^{\circ} \mathrm{C}$ and PSS 0.6, on average.

Habitat: 35\% was collected from USS, 32\% from MV and $33 \%$ from SM.

Notes: This species has two series of premaxillar teeth (Miller et al. 2005).

\section{Brycon guatemalensis Regan, 1908}

Material: Number of specimens: 1; TL: $4.5 \mathrm{~cm}$.

Distribution: Basins of the Grijalva and Usumacinta rivers in Chiapas and Tabasco in Mexico, south to western Panama on the Atlantic and the Choluteca River in Honduras on the Pacific.

Local distribution: Laguna San Isidro in $26^{\circ} \mathrm{C}$ and PSS 0.1. Habitat: This single specimen was collected from USS.

Notes: This is the only species of this genus that is distributed in the ichthyofaunistic province (Minckley et al. 2005). Its specimens are the largest of the genera Astyanax and Hyphessobrycon, and they are characterised by the upper mandible projecting further out than the lower mandible (Miller et al. 2005). It is a new record for the BRPC.

\section{Hyphessobrycon compressus (Meek, 1904)}

Material: Number of specimens: 209; TL: $1.8-6.3 \mathrm{~cm}$; TL average: $3 \mathrm{~cm}$.

Distribution: From the Papaloapan River, basin of the Tonalá River, basins of the rivers Grijalva and Usumacinta in Chiapas and Tabasco and the Hondo River, Quintana Roo in Mexico; Guatemala and northwestern Belize on the Atlantic.

Local distribution: The lagoons of Cantemoc, Chichicastle, Concepción, El Guanal, El Loncho, El Sauzo, Los Ídolos, San Isidro, San Isidro El Jobo and the 5th section of the Bitzal River in $28.7^{\circ} \mathrm{C}$ and PSS 0.5 , on average. Habitat: 43\% was collected from USS, 31\% from SM and $26 \%$ from MV.

Notes: This species is similar in shape and colour to Astyanax, but it is smaller and has a black spot on the anterobasal area of the dorsal fin (Schmitter-Soto 1998, Miller et al. 2005).

\section{ORDER SILURIFORMES FAMILY ARIIDAE Cathorops aguadulce (Meek, 1904)}

Material: Number of specimens: 1; TL: $22.5 \mathrm{~cm}$.

Distribution: The Pánuco River basin in Tamaulipas, the Papaloapan River basin and the Coatzacoalcos and Tonalá rivers in Veracruz, basins of the rivers Grijalva and Usumacinta in Chiapas and Tabasco, and Campeche, Mexico, south to the Polochic-Lago de Izabal in Guatemala on the Atlantic.

Local distribution: Laguna El Sauzo in $32^{\circ} \mathrm{C}$ and PSS 0.1. Habitat: The species was collected from USS.

Notes: From a biogeographic point of view, the ariid recorded for the Grijalva-Usumacinta Division (Marceniuk and Betancur-R. 2008) is Cathorops kailolae Marceniuk et Betancur-R., 2008. However, the specimens collected in the BRPC were identified as ] C. aguadulce as they had a shorter snout (6.8-8.6 vs. 9.3\%-11.6\% SL) and a smaller distance from the tip of the snout to the origin of the dorsal-fin (33.1-38.0 vs. $39.0 \%-40.7 \%$ SL), which are the two characteristics that separate it from its more similar congeneric species (Marceniuk and Betancur-R. 2008). 


\section{FAMILY HEPTAPTERIDAE}

Rhamdia quelen (Quoy et Gaimard, 1824)

Material: Number of specimens: 7; TL: 2-15.3 cm; TL average: $6.04 \mathrm{~cm}$.

Distribution: From the Chachalacas River in Veracruz, basin of the Tonalá River; basins of the rivers Grijalva and Usumacinta in Chiapas and Tabasco, Peninsula of Yucatán to Panama on the Atlantic, and on the Pacific from the Tehuantepec River in Chiapas to Central America.

Local distribution: El Sauzo and San Isidro El Jobo lagoons in $28.7^{\circ} \mathrm{C}$ and PSS 0.3 , on average.

Habitat: $72 \%$ was collected from USS, $14 \%$ from MV and $14 \%$ from SM.

Notes: This species differs from $R$. laticauda (Kner, 1858) and R. macuspanensis Weber et Wilkens, 1998 as it has numerous serrae on the anterior and posterior edges of the pectoral spine (Schmitter-Soto 1998, Miller et al. 2005). The three species are distributed in the Usumacinta Province (Minckley et al. 2005). This species is in a status of special protection according to the NOM-059-SEMARNAT-2010 (Anonymous 2010a).

\section{ORDER ATHERINIFORMES FAMILY ATHERINOPSIDAE Atherinella alvarezi (Díaz-Pardo, 1972)}

Material: Number of specimens: 71; TL: $2.3-7.5 \mathrm{~cm}$; TL average: $4.2 \mathrm{~cm}$.

Distribution: From Sontecomapan, Veracruz, basin of the Tonalá River; basins of the rivers Grijalva and Usumacinta in Chiapas and Tabasco, Champotón River in Campeche, south to the Caobas lagoon in Quintana Roo on the Atlantic.

Local distribution: The drains Narváez Norte and Narváez Sur, the lagoons of Cantemoc, El Sauzo, Larga, Narváez, San Isidro and San Pedrito, the 7th section of the Bitzal River and Ribera Alta 1st section (Usumacinta River) in $28.8^{\circ} \mathrm{C}$ and PSS 0.6 , on average.

Habitat: 44\% was collected from SM, 42\% from MV and $14 \%$ from USS.

Notes: This Atherinella was reported for the Usumacinta Province (Minckley et al. 2005) and differs from A. schultzi (Álvarez et Carranza, 1952) as the distal tips of the premaxilla and the maxilla do not extend further than the anterior margin of the orbit (Miller et al. 2005). Although $A$. alvarezi was recorded as endemic for the state of Tabasco by Espinosa-Pérez and Daza-Zepeda (2005), other authors recorded it for Veracruz, Campeche, Chiapas and Quintana Roo in Mexico, and for Guatemala (Reséndez-Medina 1981, Schmitter-Soto 1998, Willink et al. 2000, Rodiles-Hernández et al. 2005).

\section{ORDER BELONIFORMES FAMILY HEMIRAMPHIDAE Hyporhamphus mexicanus Álvarez, 1959}

Material: Number of specimens: 6, TL: $1.3-8.5 \mathrm{~cm}$; TL average: $4 \mathrm{~cm}$.

Distribution: Papaloapan River, basins of the rivers
Grijalva and Usumacinta in Chiapas and San Pedro River in Mexico, and Guatemala on the Atlantic.

Local distribution: Lagoon of San Pedrito and the 1st section of the Ribera Alta River (Usumacinta River) in $28.6^{\circ} \mathrm{C}$ and PSS 0.9 , on average.

Habitat: Five specimens were collected from SM and one from USS.

Notes: This vicarious species has been collected in the adjacent neritic area. It is different from the marine species $H$. roberti (Valenciennes, 1847) as it lacks scales on the inter-radial membranes of the dorsal and anal fins, and it has fewer total gill rakers (19-21) on the first branchial arch, compared with $H$. roberti that has 28-31 (Castro-Aguirre et al. 1999).

\section{ORDER CYPRINODONTIFORMES FAMILY RIVULIDAE Rivulus tenuis (Meek, 1904)}

Material: Number of specimens: 13; TL: 1.4-4.1 cm; TL average: $2.3 \mathrm{~cm}$.

Distribution: From the Antigua River, basin of the Tonalá River in Veracruz; basins of the rivers Grijalva and Usumacinta in Chiapas and Tabasco, south to Quintana Roo in Mexico and Honduras on the Atlantic.

Local distribution: Lagoons of El Loncho, San Isidro El Jobo, Cantemoc, El Tintal, Narváez and El Coco, and the 7th section of the Bitzal River in $28.8^{\circ} \mathrm{C}$ and PSS 0.6 , on average. Habitat: 69\% was collected from MV and 31\% from USS. Notes: R. tenuis differs from Kryptolebias marmoratus (Poey, 1880) by the presence of 35-41 scales on a lateral series, whereas $K$. marmoratus has 45-56 (Miller et al. 2005, Schmitter-Soto 1998). Also, K. marmoratus belongs to the ichthyofaunistic province of Yucatán (Minckley et al. 2005).

\section{FAMILY POECILIIDAE \\ Belonesox belizanus Kner, 1860}

Material: Number of specimens: 5; TL: $1.8-7.6 \mathrm{~cm}$; TL average: $4.4 \mathrm{~cm}$.

Distribution: From the Chachalacas River and the basin of the Tonalá River, Veracruz, basins of the rivers Grijalva and Usumacinta in Chiapas and Tabasco, Mexico, to Costa Rica on the Atlantic.

Local distribution: Lagoons of Cantemoc, Chichicastle, El Viento and San Pedrito in $29.5^{\circ} \mathrm{C}$ and PSS 0.6, on average.

Habitat: All specimens were collected from MV.

Notes: This species is unique for the family due to its size, strong teeth and beak-like jaws typical of predators. It also has various black points on the sides and a big spot at the base of the caudal fin (Schmitter-Soto 1998).

\section{Carlhubbsia kidderi (Hubbs, 1936)}

Material: Number of specimens: 821; TL: $0.8-5.9 \mathrm{~cm}$; TL average: $2.7 \mathrm{~cm}$.

Distribution: Basins of the Grijalva and Usumacinta rivers in Chiapas and Tabasco, and Champotón River in Campeche, Mexico; La Pasión and San Pedro rivers in Guatemala on the Atlantic. 
Local distribution: The Narváez Norte and Narváez Sur drains, the lagoons Cantemoc, El Guanal, El Loncho, El Sauzo, El Tintal, San Isidro and Sargazal in $28.8^{\circ} \mathrm{C}$ and PSS 0.6, on average.

Habitat: 95\% was collected from SM, 3\% from USS and $2 \%$ from MV.

Notes: The body of this species is characteristically rhomboidal. The dorsal fin is triangular with a black spot (Schmitter-Soto 1998, Miller et al. 2005).

\section{Gambusia sexradiata Hubbs, 1936}

Material: Number of specimens: 626; TL: 1.15-3.4 cm; TL average: $2.1 \mathrm{~cm}$.

Distribution: From northern Veracruz, basin of the Tonalá River; basins of the rivers Grijalva and Usumacinta in Chiapas and Tabasco, and Peninsula of Yucatán in Mexico, south to Honduras on the Atlantic.

Local distribution: Arroyo Punteada, drains Narváez Norte and Narváez Sur, lagoons Cantemoc, Chichicastle, Concepción, El Guanal, El Loncho, El Sauzo, El Tintal, El Viento, Landeros, Larga, Los Ídolos, Narváez, Punteada, San Isidro, San Isidro El Jobo, San Pedrito, Sargazal, Puente Frontera, the 1st section of the Ribera Alta River (Usumacinta River) and Grijalva Centro in $28.6^{\circ} \mathrm{C}$ and PSS 0.6 , on average.

Habitat: $97 \%$ was collected from MV and 3\% from USS. Notes: G. sexradiata differs from the sympatric species G. yucatana Regan, 1914 by its lateral lines of well aligned dots (Schmitter-Soto 1998, Miller et al. 2005).

Gambusia yucatana Regan, 1914

Material: Number of specimens: 244; TL: $1.2-3.5 \mathrm{~cm}$; TL average: $2.3 \mathrm{~cm}$.

Distribution: Basin of the Tonalá River in Veracruz; basins of the rivers Grijalva and Usumacinta in Chiapas and Tabasco, Peninsula of Yucatán in Mexico; northwestern Guatemala and Belize on the Atlantic.

Local distribution: Arroyo Punteada, the drain Narváez Sur, the lagoons Cantemoc, Chichicastle, Concepción, El Coco, El Cometa, El Guanal, El Loncho, El Sauzo, El Tintal, Landeros, Larga, Los Ídolos, Narváez, Punteada, San Isidro, San Isidro El Jobo, San Pedrito, Sargazal, Puente Frontera, the 5th and 7th section of the Bitzal River, Bitzal, Elpídio Sánchez (Usumacinta River) and Grijalva Centro in $28.6^{\circ} \mathrm{C}$ and PSS 0.6, on average.

Habitat: $86 \%$ was collected from MV, 12\% from SM and $2 \%$ from USS.

Notes: This Gambusia differs from G. sexradiata as the lines of dots at the sides of the body are scattered (Schmitter-Soto 1998, Miller et al. 2005).

\section{Heterandria bimaculata (Heckel, 1848)}

Material: Number of specimens: 2; TL: 1.5-3.9 cm; TL average: $2.7 \mathrm{~cm}$.

Distribution: From the Misantla River in Veracruz, the Grijalva and Usumacinta rivers in Chiapas and Tabasco, Campeche, Yucatán, Quintana Roo in Mexico, to the Prinzapolka River in Nicaragua on the Atlantic.
Local distribution: The Narváez Sur drain in $31^{\circ} \mathrm{C}$ and PSS 0

Habitat: The two specimens were collected from MV.

Notes: This species is the only of the genus Heterandria recorded for the División Grijalva-Usumacinta (Minckley et al. 2005). It differs from $H$. jonesii (Günther, 1874), its closer congenus recorded for the División PapaloapanCoatzacoalcos (Minckley et al. 2005), by having a greater number of rays in the dorsal fin (modally 14) than H. jonesii (modally 8-12) (Schmitter-Soto 1998, Miller et al. 2005).

\section{Heterophallus aff. rachovii}

Material: Number of specimens: 245; TL: $0.7-3.4 \mathrm{~cm}$; TL average: $1.9 \mathrm{~cm}$.

Distribution: H. rachovii Regan, 1914 has been recorded in the middle region of the Coatzacoalcos River in Veracruz.

Local distribution: The dredged canal San Román, the drains Narváez Norte and Narváez Sur, the lagoons El Cometa, Chichicastle, El Coco, El Guanal, El Loncho, El Sauzo, the 5th section of the Bitzal River and 1st section of the Ribera Alta River (Usumacinta River) in $28.7^{\circ} \mathrm{C}$ and PSS 0.7 , on average.

Habitat: $92.2 \%$ was collected from MV , $4.5 \%$ from USS and $3.3 \%$ from SM.

Notes: The main characteristic of the specimens of $H$. affof. rachovii is a small perpendicular membranous hood on the point of the fourth ray, which is very prominent in H. milleri Radda, 1987 and Gambusia echeagarayi (Álvarez, 1952), two species that have been recorded for the basins of the rivers Grijalva and Usumacinta in Tabasco and Chiapas (Miller et al. 2005). Part of the material is being processed in the National Fish Collection, Instituto de Biología, Universidad Nacional Autónoma de México. This is a first record for the Usumacinta Province and the BRPC.

Phallichthys fairweatheri Rosen et Bailey, 1959 Material: Number of specimens: 126; TL: 1-3.8 cm; TL average: $2.6 \mathrm{~cm}$.

Distribution: Basin of the Tonalá River; basins of the rivers Grijalva and Usumacinta in Chiapas and Tabasco, southern Campeche and Quintana Roo in Mexico; northern Guatemala and Belize, basin of the Hondo River on the Atlantic.

Local distribution: The drain Narváez Sur, the lagoons Cantemoc, Chichicastle, Concepción, El Guanal, El Loncho, El Sauzo, El Tintal, Landeros, Los Ídolos, San Isidro, San Isidro El Jobo, Sargazal, Puente Frontera, and the 5 th section of the Bitzal River in $28.8^{\circ} \mathrm{C}$ and PSS 0.5, on average.

Habitat: $97 \%$ was collected from MV and 3\% from USS. Notes: This species is the only one representing the genus Phallichthys in the División Grijalva-Usumacinta. It differs from $P$. amates (Miller, 1907), its closest congenus, by having 10 rays in the dorsal fin and well defined dark vertical bars on the sides of the body, while $P$. amates has 
nine rays in the dorsal fin and badly defined lateral bars on the sides of the body (Schmitter-Soto 1998, Miller et al. 2005). This is a new record for the study area.

Poecilia mexicana Steindachner, 1863

Material: Number of specimens: 23; TL: $1.3-6.8 \mathrm{~cm}$; TL average: $2.9 \mathrm{~cm}$.

Distribution: Coastal plain of the Gulf of Mexico from the San Juan River, Nuevo León, basin of the Tonalá River, basins of the rivers Grijalva and Usumacinta in Chiapas and Tabasco, and the peninsula of Yucatán in Mexico, south to Guatemala on the Atlantic, upper stretch of the Choluteca River, Honduras on the Pacific.

Local distribution: Arroyo Punteada, the drains Narváez Norte and Narváez Sur, the lagoons El Loncho, El Sauzo, Landeros, San Isidro El Jobo, Sargazal, Puente Frontera, and the 5th section of the Bitzal River in $28.9^{\circ} \mathrm{C}$ and PSS 0.5, on average.

Habitat: $88 \%$ was collected from MV and 12\% from USS. Notes: This species differs from P. petenensis Günther, 1866, also recorded for Tabasco, by having fewer dorsal rays (9-10) in comparison with 12-14 (Schmitter-Soto 1998, Miller et al. 2005).

Poecilia petenensis Günther, 1866

Material: Number of specimens: 2; TL: $2.6-4.0 \mathrm{~cm}$; TL average: $3.3 \mathrm{~cm}$.

Distribution: Basin of the Tonalá River; basins of the rivers Grijalva and Usumacinta in Chiapas and Tabasco; Campeche and Quintana Roo in Mexico; northern Belize and Guatemala on the Atlantic.

Local distribution: Lagoon El Sauzo in $32^{\circ} \mathrm{C}$ and PSS 0.5. Habitat: The specimens were collected from MV.

Xiphophorus maculatus (Günther, 1866)

Material: Number of specimens: 8; TL: $2.2-3.4 \mathrm{~cm}$; TL average: $2.55 \mathrm{~cm}$.

Distribution: Basins of the rivers Coatzacoalcos, Papaloapan and Tonalá in Veracruz; basins of the rivers Grijalva and Usumacinta in Chiapas and Tabasco; Campeche and Quintana Roo in Mexico, to Honduras on the Atlantic.

Local distribution: The lagoons of Los Ídolos and San Isidro El Jobo in $28.6^{\circ} \mathrm{C}$ and PSS 0.4 , on average.

Habitat: The specimens were collected from MV.

Notes: This species differs from Xiphophorus hellerii Heckel, 1848 as the males lack a spade and the body is shorter and higher (Schmitter-Soto 1998, Miller et al. 2005). Both species have been recorded for the basins of the rivers Grijalva and Usumacinta in Tabasco and Chiapas (Lozano-Vilano and Contreras-Balderas 1987, EspinosaPérez and Daza-Zepeda 2005, Miller et al. 2005).

\section{ORDER GASTEROSTEIFORMES FAMILY SYNGNATHIDAE Microphis brachyurus (Bleeker, 1854)}

Material: Number of specimens: 10; TL: $1.5-12.1 \mathrm{~cm}$; TL average: $9.0 \mathrm{~cm}$.
Distribution: From North Carolina to Uruguay, Cuba, Antilles, coastal plain of the Gulf of Mexico, basin of the Tonalá River and basin of the Grijalva River in Tabasco, Mexico.

Local distribution: Arroyo Punteada, the dredged canal San Román, the lagoons of El Sauzo, Los Ídolos, San Pedrito, Puente Frontera, and the Grijalva Centro River in $27.7^{\circ} \mathrm{C}$ and PSS 0.6 , on average.

Habitat: $90 \%$ was collected from MV and 10\% from USS. Notes: This is a marine species frequently distributed in the seagrass Thalassia testudinum and in reefs, which has invaded estuarine ecosystems, rivers, and other limnetic environments of the eastern Mexican coast (CastroAguirre et al. 1999). It is a new record for the BRPC.

\section{ORDER SYNBRANCHIFORMES FAMILY SYNBRANCHIDAE \\ Ophisternon aenigmaticum Rosen et}

Greenwood, 1976

Material: Number of specimens: 24; TL: 3-19 cm; TL average: $6.5 \mathrm{~cm}$.

Distribution: From the Chachalacas and Tonalá rivers in Veracruz, basins of the rivers Grijalva and Usumacinta in Tabasco and Chiapas, and the peninsula of Yucatán in Mexico, to the Motagua River basin, Guatemala and Honduras on the Atlantic; one record near Tapachula, Chiapas on the Pacific.

Local distribution: Arroyo Punteada, the Narváez Norte drain, the lagoons Cantemoc, Chichicastle, El Coco, El Loncho, Sargazal, El Viento, Landeros, Larga, Los Ídolos and San Isidro El Jobo in $29^{\circ} \mathrm{C}$ and PSS 0.5 , on average. Habitat: $87 \%$ was collected from MV and 13\% from USS. Notes: In this species, the gill opening is transversal and half moon shaped. This particular characteristic separates it from Synbranchus marmoratus Bloch, 1795 that presents it as a sunk pore between tissue folds (Schmitter-Soto 1998, Miller et al. 2005). It is a new record for the BRPC.

\section{ORDER PERCIFORMES FAMILY GERREIDAE \\ Diapterus auratus Ranzani, 1842}

Material: Number of specimens: 7; TL: $1.6-4.8 \mathrm{~cm}$; TL average: $4 \mathrm{~cm}$.

Distribution: From North Carolina, USA, to Brazil; Antilles; coastal plain of the Gulf of Mexico from Laguna Madre, Tamaulipas, the basin of the Tonalá River, the basins of the rivers Grijalva and Usumacinta in Chiapas and Tabasco, the peninsula of Yucatán in Mexico; Caribbean sea.

Local distribution: The lagoons of El Coco and El Cometa in $28.3^{\circ} \mathrm{C}$ and PSS 1.6, on average.

Habitat: These specimens were collected from USS.

Notes: This species has three spines and eight anal rays and 12-15 gill rakers on the first branchial arch in contrast with D. rhombeus (Cuvier, 1829) that has anal fin II, 9 and 16-18 gill rakers (Schmitter-Soto 1998, Miller et al. 2005). It is a new record for the BRPC. 


\section{FAMILY SCIAENIDAE}

Bairdiella chrysoura (Lacepède, 1802)

Material: Number of specimens: 1; TL: $4.1 \mathrm{~cm}$.

Distribution: From Massachusetts, USA, to Veracruz, and in the lagoon system of El Carmen-MachonaRedonda in Tabasco Mexico, on the Atlantic.

Local distribution: El Viento lagoon in $30.5^{\circ} \mathrm{C}$ and PSS 0.2. Habitat: The only specimen of this species was collected from USS.

Notes: This species is a new record for the BRPC. It differs from B. ronchus (Cuvier, 1830) by having a shorter spine that does not reach the base of the caudal fin (Castro-Aguirre et al. 1999).

\section{FAMILY CICHLIDAE}

Amphilophus robertsoni (Regan, 1905)

Material: Number of specimens: 6; TL: $2.4-15.2 \mathrm{~cm}$; TL average: $7.8 \mathrm{~cm}$.

Distribution: Basins of the Coatzacoalcos River, the Tonalá River, and the Grijalva and Usumacinta rivers, also in Chiapas and Tabasco, Mexico, south to Honduras on the Atlantic.

Local distribution: The drain Narváez Sur, the lagoons El Guanal and San Isidro in $28.8^{\circ} \mathrm{C}$ and PSS 0.7 , on average. Habitat: 50\% was collected from MV, 33\% from USS and $17 \%$ from SM.

Notes: This species differs from the other cichlids on this list by having a robust body with a vivid yellowish green colour, a pattern of thin transversal bars and lips generally expanded or thickened with teeth sunk in the gums (Miller et al. 2005).

\section{Chichlasoma pearsei (Hubbs, 1936)}

Material: Number of specimens: 1; TL: $3.6 \mathrm{~cm}$.

Distribution: Basins of the rivers Grijalva and Usumacinta in Chiapas and Tabasco, also Campeche, Mexico, south to Petén, Guatemala, on the Atlantic.

Local distribution: The 5th section of the Bitzal River in $30^{\circ} \mathrm{C}$ and PSS 1 .

Habitat: This single specimen was collected from MV.

Notes: This species differs from the other native cichlids recorded for the División Grijalva-Usumacinta, as its middle mandibular teeth of the external series are compressed and spatulate (Miller et al. 2005).

\section{Cichlasoma salvini (Günther, 1862)}

Material: Number of specimens: 170; TL: 1.6-10.7 cm; TL average: $4.1 \mathrm{~cm}$.

Distribution: Basins of the rivers Papaloapan, Tonalá, Grijalva, and Usumacinta, in Chiapas and Tabasco, Mexico, south to Guatemala on the Atlantic.

Local distribution: Arroyo Punteada, the drains Narváez Norte and Narváez Sur, the lagoons Cantemoc, Chichicastle, Concepción, El Guanal, El Loncho, Sargazal, El Sauzo, El Viento, Landeros, Larga, Los Ídolos, Narváez, Punteada, San Isidro, San Isidro El Jobo, San Pedrito, the 5th section of the Bitzal River, Elpídio Sánchez (Usumacinta River) and Grijalva Centro in $28.7^{\circ} \mathrm{C}$ and PSS 0.6, on average.
Habitat: $87 \%$ was collected from MV, 9\% from SM and $4 \%$ from USS.

Notes: This Cichlasoma has a characteristic band-like dark spot that starts at the mouth and ends at the dorsal area of the caudal peduncle, passing through the eye. It does not bear spots on the caudal fin, which makes it easy to tell it apart from other species of the same group (Schmitter-Soto 1988, Miller et al. 2005).

Cichlasoma urophthalmum (Günther, 1862)

Material: Number of specimens: 66; TL: $1.7-17.5 \mathrm{~cm}$; TL average: $4.3 \mathrm{~cm}$.

Distribution: Basin of the Tonala River; basins of the rivers Grijalva and Usumacinta in Chiapas and Tabasco, Mexico to Nicaragua.

Local distribution: Arroyo Punteada, the drains Narváez Norte and Narváez Sur, the lagoons Cantemoc, Chichicastle, Concepción, El Guanal, El Loncho, El Sauzo, El Tintal, Landeros, Los Ídolos, San Isidro, San Isidro El Jobo, Sargazal, the 7th section of the Bitzal River in $28.8^{\circ} \mathrm{C}$ and PSS 0.5 , on average.

Habitat: $88 \%$ was collected from MV, 9\% from SM and $3 \%$ from USS.

Notes: This species is different from the other species of the genus Cichlasoma as it has a caudal ocellus and 5-7 well defined dark vertical bands on the sides of the body (Schmitter-Soto 1998, Miller et al. 2005).

\section{Oreochromis niloticus (L.)}

Material: Number of specimens: 1; TL: $23.2 \mathrm{~cm}$.

Distribution: Africa. Widely distributed as a result of being introduced for aquacultural purposes.

Local distribution: The 5th section of the Bitzal River in $29^{\circ} \mathrm{C}$ and PSS 0.1 .

Habitat: This specimen was collected from USS.

Notes: Although O. aureus (Steindachner, 1864) and O. mossambicus (Peters, 1852) have not been reported for the study area, $O$. niloticus differs from both by presenting a pink-purple body, a dorsal black border and a caudal fin with defined vertical bars that follow a white-dark colour pattern. The species was introduced from Panama into Mexico in 1964 for aquacultural purposes (Morales 2003, Schmitter-Soto 2006).

\section{Parachromis friedrichsthalii (Heckel, 1840)}

Material: Number of specimens: 3; TL: 2.8-20.7 cm; TL average: $11.9 \mathrm{~cm}$.

Distribution: Basins of the Tonalá and Coatzacoalcos rivers in Veracruz; basins of the rivers Grijalva and Usumacinta in Chiapas and Tabasco, Mexico, south to Belize on the Atlantic.

Local distribution: Narváez, San Isidro and El Coco lagoons in $29^{\circ} \mathrm{C}$ and PSS 0.7 , on average.

Habitat: $67 \%$ was collected from MV and 33\% from USS. Notes: P. friedrichsthali has four mandibular pores whereas P. motaguensis (Günther, 1867) has five. Also, P. friedrichsthalii has 8-13 gill rakers on the first branchial arch and P. managuensis (Günther, 1867) has 14-17. The species 
P. managuensis and $P$. motaguensis were introduced for aquaculture into southern Mexico (Usumacinta River) (Schmitter-Soto 1998, Miller et al. 2005). P. friedrichsthalii was categorised by the IUCN as a "least concern species" (Snoeks et al. 2007).

Paraneetroplus synspilus (Hubbs, 1935)

Material: Number of specimens: 38; TL: 1.9-15 cm; TL average: $3.5 \mathrm{~cm}$.

Distribution: Basin of the Tonala River, basins of the rivers Grijalva and Usumacinta in Chiapas and Tabasco, Quintana Roo, in Mexico; Petén, Guatemala and Belize, on the Atlantic.

Local distribution: Arroyo Punteada, the drain Narváez Sur, the lagoons Chichicastle, El Coco, El Loncho, El Sauzo, El Tintal, Landeros, Narváez, Punteada, San Isidro, San Pedrito, Sargazal, the 7th section of the Bitzal River and the 1st section of the Ribera Alta River (Usumacinta River) in $28.9^{\circ} \mathrm{C}$ and PSS 0.6 , on average.

Habitat: 91\% was collected from MV and 3\% from each of SM, USS and CWD.

Notes: The presence of three or more joined spots on the posterior side, projected towards the front and upwards from the caudal base to the point of the pectoral fin, differ it from Theraps heterospilus (Hubbs, 1936) that has slightly defined bands at the body sides (Miller et al. 2005).

\section{Petenia splendida Günther, 1862}

Material: Number of specimens: 23; TL: $1.6-4.9 \mathrm{~cm}$; TL average: $3.1 \mathrm{~cm}$.

Distribution: Basin of the Tonalá River; basins of the rivers Grijalva and Usumacinta in Chiapas and Tabasco; Campeche and Quintana Roo in Mexico, south to Guatemala and Belize on the Atlantic.

Local distribution: Arroyo Punteada, the drains Narváez Norte and Narváez Sur, the lagoons Cantemoc, El Sauzo, Larga, San Isidro, San Isidro El Jobo, San Pedrito, Sargazal, and the Elpídio Sánchez River (Usumacinta River) in $28.7^{\circ} \mathrm{C}$ and PSS 0.6 , on average.

Habitat: $76 \%$ was collected from MV and $24 \%$ from USS. Notes: This cichlid differs from the other species of the family by having a yellowish elongate body with nine black rounded spots throughout the length of the body, and a big and markedly protrusible mouth (SchmitterSoto 1998, Miller et al. 2005).

\section{Rocio octofasciata (Regan, 1903)}

Material: Number of specimens: 4; TL: $6.8-8.6 \mathrm{~cm}$; TL average: $8.1 \mathrm{~cm}$.

Distribution: Basin of the Tonalá River, basins of the rivers Grijalva and Usumacinta in Chiapas and Tabasco; Peninsula of Yucatán in Mexico, to Honduras on the Atlantic.

Local distribution: Arroyo Punteada, the lagoons of San Isidro El Jobo and El Guanal in $28.3^{\circ} \mathrm{C}$ and PSS 0.6, on average.

Habitat: $75 \%$ was collected from MV and $25 \%$ from USS. Notes: This species has a short snout and a smallish mouth, the caudal, dorsal and anal fins are covered by spots or small points, and it has a caudal ocellus and two dark lines between the eyes. $R$. octofasciata has a dark line similar to Cichlasoma salvini, but reaching only to mid body (Schmitter-Soto 1998, Miller et al. 2005).

Theraps heterospilus (Hubbs, 1936)

Material: Number of specimens: 20; TL: $2-11 \mathrm{~cm}$; TL average: $3.6 \mathrm{~cm}$.

Distribution: Basin of the Coatzacoalcos River, basins of the rivers Grijalva and Usumacinta in Chiapas and Tabasco in Mexico, to Guatemala on the Atlantic.

Local distribution: The lagoons Cantemoc, Chichicastle, El Coco, El Guanal, El Loncho, El Sauzo, El Tintal, Larga, San Pedrito, Puente Frontera, and the 5th section of the Bitzal River and Elpídio Sánchez (Usumacinta River) in $28.4^{\circ} \mathrm{C}$ and PSS 0.6 , on average.

Habitat: $80 \%$ was collected from MV and 20\% from SM. Notes: This species differs from Paraneetroplus synspilus (Hubbs, 1935) by having irregular spots or a series of partial vertical bars and a big quadrangular spot at the centre of the base of the caudal peduncle (Miller et al. 2005).

Thorichthys helleri (Steindachner, 1864)

Material: Number of specimens: 234; TL: 1.5-16 cm; TL average: $4.7 \mathrm{~cm}$.

Distribution: Basin of the Tonalá River, basins of the rivers Grijalva and Usumacinta in Chiapas and Tabasco, northwestern Peninsula of Yucatán in Mexico, to the limits of Guatemala and Belize on the Atlantic.

Local distribution: The drain Narváez Sur, the lagoons Cantemoc, Chichicastle, Concepción, El Guanal, El Loncho, El Sauzo, El Tintal, Landeros, Larga, Los Ídolos, Punteada, San Isidro and San Isidro El Jobo in $28.8^{\circ} \mathrm{C}$ and PSS 0.5 , on average.

Habitat: $74 \%$ was collected from USS, $25 \%$ from SM and $1 \%$ from MV.

Notes: It does not have a scaly sheath typical for Thorichthys group and also differs from the next two species by having a yellow anal fin and branchiostegal membranes that are not dark, while alive (Miller et al. 2005).

Thorichthys meeki Brind, 1918

Material: Number of specimens: 188; TL: 2.2-11.7 cm; TL average: $5.9 \mathrm{~cm}$.

Distribution: Basin of the Tonalá River, basins of the rivers Grijalva and Usumacinta in Chiapas and Tabasco, Peninsula of Yucatán, Mexico, and northern Belize on the Atlantic.

Local distribution: The drain Narváez Sur, the lagoons Chichicastle, El Guanal, El Loncho, El Sauzo, El Tintal, Landeros, Larga, Los Ídolos, Punteada, San Isidro, San Isidro El Jobo, San Pedrito and Sargazal in $29^{\circ} \mathrm{C}$ and PSS 0.6 , on average.

Habitat: $89 \%$ was collected from USS, $10 \%$ from SM and $1 \%$ from MV.

Notes: This species is different from T. helleri and T. pasionis (Rivas, 1962) due to the red color in the throat 
and the abdomen, while alive (Schmitter-Soto 1998, Miller et al. 2005).

Thorichthys pasionis (Rivas, 1962)

Material: Number of specimens: 121; TL: 1.6-12 cm; TL average: $5.7 \mathrm{~cm}$.

Distribution: Basins of the rivers Grijalva and Usumacinta in Chiapas and Tabasco, southwestern Campeche in Mexico and Guatemala, on the Atlantic.

Local distribution: The drain Narváez Sur, the lagoons Cantemoc, Chichicastle, Concepción, El Guanal, El Loncho, El Sauzo, El Tintal, Landeros, Larga, Los Ídolos, Punteada, San Isidro and San Isidro El Jobo in $28.8^{\circ} \mathrm{C}$ and PSS 0.5 , on average.

Habitat: 78\% was collected from USS, 20\% from SM and $2 \%$ from MV.

Notes: This cichlid differs from T. meeki and T. pasionis, reported for the study area, by having a small dark spot on each scale of the upper lateral line and black branchiostegal membranes (Miller et al. 2005).

\section{FAMILY ELEOTRIDAE}

Dormitator maculatus (Bloch, 1792)

Material: Number of specimens: 143; TL: 0.7-18.9 cm; TL average: $2.9 \mathrm{~cm}$.

Distribution: Along the Atlantic from North Carolina, USA, to Brazil; Bahamas; Antilles; on the coastal plain of the Gulf of Mexico in the basin of the Tonalá River; and the basins of the rivers Grijalva and Usumacinta in Tabasco, Mexico.

Local distribution: Arroyo Punteada, the dredged canal San Román, the drains Narváez Norte and Narváez Sur, the lagoons Cantemoc, Concepción, El Coco, El Guanal, El Viento, Landeros, Larga, Los Ídolos, Punteada, El Sauzo, San Isidro, San Isidro El Jobo, San Pedrito, the Grijalva Centro River and the 1st section of the Ribera Alta River (Usumacinta River) in $28.4^{\circ} \mathrm{C}$ and PSS 0.6, on average.

Habitat: 94\% was collected from MV, 3\% from CWD, $2 \%$ from SM and $1 \%$ from USS.

Notes: This genus differs from Gobiomorus and Eleotris by having 31-35 scales on the lateral series and a thin dark line from the anterior area of the eye to the posterior area of the mandible (Schmitter-Soto 1998, Miller et al. 2005).

\section{Eleotris amblyopsis (Cope, 1871)}

Material: Number of specimens: 7; TL: $1.8-4.2 \mathrm{~cm}$; TL average: $3.2 \mathrm{~cm}$.

Distribution: From central-northern Veracruz in the basin of the Tonalá River, Mexico to Surinam on the Atlantic.

Local distribution: El Coco lagoon, Puente Frontera and the 1 st section of the Ribera Alta River (Usumacinta River) in $28.6^{\circ} \mathrm{C}$ and PSS 0.6, on average.

Habitat: $86 \%$ was collected from MV and 14\% from CWD. Notes: The presence of a small spine hidden in the angle of the preopercle, 50-56 scales on a lateral series of the body, and the pectoral fin reaching or passing the base of the anal fin, make this species different from Dormitator maculatus and Gobiomorus dormitor (Miller et al. 2005).

Gobiomorus dormitor Lacépede, 1800

Material: Number of specimens: 112; TL: 1-3.4 cm; TL average: $2 \mathrm{~cm}$.

Distribution: From southern Florida, USA, coastal plain of the Gulf of Mexico in the basin of the Tonala River, and the basins of the rivers Grijalva and Usumacinta in Chiapas and Tabasco, Mexico to northern Brazil on the Atlantic.

Local distribution: Arroyo Punteada, the drains Narváez Norte and Narváez Sur, the lagoons El Cometa, El Coco, El Guanal, El Loncho, El Sauzo, El Tintal, El Viento, Los Ídolos, Punteada, San Isidro, San Isidro El Jobo, San Pedrito, Puente San Pedro y San Pablo, the rivers Grijalva Centro and the 1st section of the Ribera Alta River (Usumacinta River) in $28.5^{\circ} \mathrm{C}$ and PSS 0.8 , on average.

Habitat: $62 \%$ was collected from MV and $38 \%$ from USS. Notes: The presence of 55-62 scales on a lateral series of the body, the sides of the body with a series of semicircular dark spots on the lateral line from the snout to the caudal peduncle, and a dark spot on the distal area of the first dorsal fin, make this species different from Dormitator maculatus and Eleotris amblyopis (see Miller et al. 2005).

\section{FAMILY GOBIIDAE \\ Ctenogobius claytonii (Meek, 1902)}

Material: Number of specimens: 5; TL: 2-3.9 cm; TL average: $2.5 \mathrm{~cm}$.

Distribution: From southern Texas, USA to Pajaritos Lagoon near Coatzacoalcos, Veracruz, Mexico on the Atlantic.

Local distribution: The lagoons El Coco, El Cometa, San Isidro and San Pedrito in $28.8^{\circ} \mathrm{C}$ and PSS 1.2 , on average.

Habitat: 61\% was collected from USS, 28\% from SM, and $11 \%$ from CWD.

Notes: It is characteristic of this family for the pelvic fins to be joined forming an adhesive disc that allows them to remain attached to the bottom. The species present a spear shaped caudal fin and 30-40 scales on a lateral series (Miller et al. 2005). This species represents a new record for the Usumacinta Province and the BRPC.

Gobionellus oceanicus (Pallas, 1770)

Material: Number of specimens: 15 ; TL: $1.2-5.8 \mathrm{~cm}$; TL average: $3.7 \mathrm{~cm}$.

Distribution: From North Carolina, USA, to Campeche, Mexico including the basins of the rivers Tonalá and Grijalva in Tabasco on the Atlantic.

Local distribution: The lagoons El Coco, El Cometa, San Isidro and San Pedrito in $28.8^{\circ} \mathrm{C}$ and PSS 1.2 , on average.

Habitat: $67 \%$ was collected from USS and 33\% from MV. Notes: This species represents a new record for the BRPC. The specimens were collected in oligohaline and limnetic environments, which partly agree with two other 
records for oligohaline environments: Tampa, Fla. and Laguna de Alvarado, southern Gulf of Mexico. However, most specimens of this species have been recorded for brackish and marine environments, and some for hyperhaline areas (Castro-Aguirre et al. 1999).

\section{ORDER PLEURONECTIFORMES FAMILY PARALICHTHYIDAE Citharichthys spilopterus Günther, 1862}

Material: Number of specimens: 2; TL: $4.2-4.6 \mathrm{~cm}$; TL average: $4.4 \mathrm{~cm}$.

Distribution: From New Jersey to Florida and the Gulf of Mexico in the USA, through the Caribbean, to Brazil. On the coastal plain of the Gulf of Mexico in the basin of the Tonalá River and the basin of the Usumacinta River in Tabasco, Mexico.

Local distribution: El Coco Lagoon in $31^{\circ} \mathrm{C}$ and PSS 1.6. Habitat: The specimens were collected from USS.

Notes: It represents a new record for the BRPC.

\section{FAMILY ACHIRIDAE}

Achirus lineatus (L.)

Material: Number of specimens: 3; TL: 1.5-1.6 cm; TL average: $1.53 \mathrm{~cm}$.

Distribution: From Florida, USA to Uruguay; the basin of the Tonalá River in the Gulf of Mexico on the Atlantic. Local distribution: El Cometa Lagoon in $31^{\circ} \mathrm{C}$ and PSS 2.5. Habitat: All specimens were collected from USS. Notes: It represents a new record for the BRPC.

\section{DISCUSSION}

The nomenclature of the 11 species was updated in this study. Nine species of native cichlids were relocated in six genera considering the proposals of Miller et al. (2005), Chakrabarty (2007), Schmitter-Soto (2007), López-Fernández et al. (2010) and McMahan et al. (2010). The cichlids that were reassigned were Amphilophus robertsoni, Parachromis friedrichsthalii, Paraneetroplus synspilus, Rocio octofasciata, Theraps heterospilus, Thorichthys helleri, T. meeki, and T. pasionis. Additionally, Gobionellus claytonii was found to be synonymous with Ctenogobius claytonii, as did Gobionelus hastatus with G. oceanicus (Carpenter 2002a, b; Nelson et al. 2004, McEachran and Fechhelm 2005). The pale catfish, Rhamdia quelen, previously in the Pimelodidae family, was placed by Bockmann and Guazzelli (2003) in the Heptapteridae family and is, at present, a synonym of Rhamdia guatemalensis (Ferraris 2007).

In México, the continental fish include about 495 freshwater species (Miller et al. 2005) which have been grouped in eight ichthyofaunistic provinces (Minckley et al. 2005) that mainly correspond to the great hydrographic basins. The BRPC is located in the Usumacinta Province, Grijalva-Usumacinta Division (Minckley et al. 2005), where the basins of the rivers Papaloapan, Coatzacoalcos, and Grijalva-Usumacinta, as well as the Peninsula of Yucatán, are located. More than 200 fish species have been recorded for the Usumacinta Province (Espinosa-Pérez et al. 1998, Minckley et al. 2005, Anonymous 2010b), of which 44 were collected in this study. The Poeciliidae and Cichlidae were the most diverse families in the BRPC, coinciding with the data of Minckley et al. (2005) for the Usumacinta Province. Of the approximately 23 and 29 species of poeciliids and cichlids that are distributed in the Usumacinta Province (Lozano-Vilano and ContrerasBalderas 1987, Minckley et al. 2005), 10 and 13 were collected in this study. Of the 18 species of marine origin that have become permanent residents of the freshwater bodies in this province (Castro-Aguirre et al. 1999, Minckley et al. 2005), only Hyporhamphus mexicanus was recorded, and it is considered endemic to the basin of the high Grijalva and Usumacinta (Castro-Aguirre et al. 1999, Miller et al. 2005). Only 14 endemic species, of approximately 52 reported for the Usumacinta Province, were collected in the BRPC (de la Vega 2003, Minckley et al. 2005, Anonymous 2010b), and this is because the greatest endemism has been recorded for the high basins of the rivers Usumacinta and Grijalva (Lozano-Vilano and Contreras-Balderas 1987, Miller et al. 2005, RodilesHernández et al. 2005). Of the species collected in this study, $86 \%$ and $70 \%$ were recorded previously for the Papaloapan-Coatzacoalcos and Yucatán Divisions, respectively (Miller et al. 2005, Minckley et al. 2005, Anonymous 2010b).

Of the 44 species collected in this study, the distribution of only the characids Astyanax aeneus and Brycon guatemalensis, the heptapterid Rhamdia quelen, and the introduced Nile tilapia, Oreochromis niloticus, was extended to the other two divisions of the Usumacinta Province. The occasional capture of $R$. quelen in the BRPC coincided with the low abundance it has presented in other limnetic ecosystems (Lozano-Vilano and Contreras-Balderas 1987, Gamboa-Pérez 1992, GasparDillanes 1996, Reséndez-Medina and Salvadores 2000, Chávez-López et al. 2005, Corona 2005, RodilesHernández et al. 2005, Castillo-Domínguez et al. 2011). The Nile tilapia, $O$. niloticus was introduced into Mexico in 1964 for aquacultural purposes, and since then it has become one of the exotic species that has dispersed widely throughout the freshwater ecosystems of Mexico (Morales 2003, Schmitter-Soto 2006).

A total of $38 \%$ of the species included in this study have been recorded previously for the GrijalvaUsumacinta Division of the Usumacinta Province (Minckley et al. 2005). Of these species, 52\% correspond to the secondary freshwater component, $18 \%$ to the marine component, $14 \%$ to the primary freshwater component, $9 \%$ to the estuarine component, and the other $7 \%$ to the vicarious component. The dominance of the freshwater ichthyofauna is explained by the restricted spatial influence of the tides in the BRPC (Sánchez et al. 2007). The presence of fish of the estuarine and marine components is mainly related to trophic migrations and to their osmoregulatory capacity (Castro-Aguirre et al. 1999). Vicarious species are important as they provide evidence of a marine ancestry (Castro-Aguirre et al. 1999). 
The species Anchoa parva, Heterophallus aff. rachovii, and Ctenogobius claytonii are new records for the Usumacinta-Grijalva Division (Table 2). Anchoa parva is distributed in estuarine and marine ecosystems (Austin 1971, Castro-Aguirre et al. 1999, Sánchez and Rueda 1999, Caballero-Vázquez et al. 2005) of northern Yucatán and the Mexican Caribbean Sea, in the División Yucatán of the Usumacinta province (Schmitter-Soto 1998, CastroAguirre et al. 1999). In contrast, $H$. aff. rachovii and C. claytonii were confined to the PapaloapanCoatzacoalcos Division (Castro-Aguirre et al. 1999, Espinosa-Pérez and Daza-Zepeda 2005, Miller et al. 2005, Anonymous 2010b). The little anchovy and the gobiid C. claytonii were mainly distributed in SV and MV (Table 2) in the Tres Brazos sub-basin, where the influence of the tides is present mainly during the season of minimum flooding (Sánchez et al. 2007). The poeciliid $H$. aff. rachovii has a wide distribution and a high abundance in the study area. These three species are mostly small omnivores (Parra et al. 1984, Schmitter-Soto 1998, Miller et al. 2005, Froese and Pauly 2011) with a distribution that is mainly associated with SM and MV, as is commonly recorded for similar species in coastal wetlands (Cetra and Petrere 2007, Montalvo-Urgel et al. 2010, Rozas and Minello 2010). The structure and function of shallow aquatic communities are regulated by the trophic dynamics of these species, as they are generally mesograzers or predators, as well as prey of top predators in shallow ecosystems (Warfe and Barmuta 2006, Jorgensen et al. 2007).

The BRPC is a high priority wetland in Mexico. It is included among the 174 Natural Protected Areas of Mexico (Anonymous 2010c), and is recognised by the Ramsar Convention (Anonymous 2011b). However, the inventory of fish was incomplete as, of the 44 fish species listed in this catalogue, only 25 agreed with the previously reported checklist for this area and the San Pedro River that joins the Reserve at its eastern margin (Chávez et al. 1989, Reséndez-Medina and Salvadores 2000, CastilloDomínguez et al. 2011). Moreover, there were more similar species (31) with the lists published by EspinosaPérez and Daza-Zepeda (2005) and Miller et al. (2005), although they included the BRPC but did not represent it exclusively, as did the preliminary inventory published by Reséndez-Medina and Salvadores (2000). Only Rhamdia quelen, Cichlasoma pearsei, Cichlasoma urophthalmum, and Petenia splendida were recorded in this catalogue and the five previous studies. In contrast, Anchoa parva, Heterophallus aff. rachovii, Microphis brachyurus, Diapterus auratus, Bairdiella chrysoura, Ctenogobius claytonii, Gobionellus oceanicus, Citharichthys spilopterus, and Achirus lineatus are not in the five abovementioned publications. Of these nine species, A. parva, $H$. aff. rachovii, $M$. brachyurus, and $C$. claytonii were collected mostly from one of the structured habitats (Table 2). The scieanid B. chrysoura has been frequently cited for the coastal lagoons of the southern Gulf of Mexico and associated limnetic ecosystems (Reséndez-Medina 1980, 1981, Yáñez-Arancibia 1988, Reséndez-Medina and
Kobelkowsky-Díaz 1991, Ayala-Pérez et al. 1998), as it is a migratory euhaline marine species that tolerates salinities from PSS 0.5 to PSS 45.5 (Castro-Aguirre et al. 1999). The poeciliid Phallichthys fairweatheri, the syngnathid Microphis brachyurus, and the gerreid Diapterus auratus have been recorded for other aquatic environments of the Grijalva-Usumacinta Division and Usumacinta Province (Reséndez-Medina 1980, Lozano-Vilano and ContrerasBalderas 1987, Schmitter-Soto 1998, Espinosa-Pérez and Daza-Zepeda 2005, Miller et al. 2005, Rodiles-Hernández et al. 2005, Anonymous 2010b, Castillo-Domínguez et al. 2011), although not for the BRPC.

Papers published for the BRPC and the limnetic ecosystems of the Usumacinta-Grijalva basin have reported studies that were carried out with different sampling designs, mostly in USS (Chávez et al. 1989, Reséndez-Medina and Salvadores 2000, CastilloDomínguez et al. 2011). Among these, Reséndez-Medina and Salvadores (2000) recorded 13 species that were not collected in this study, of which $31 \%$ belong to the estuarine component and the rest includes freshwater (23\%), vicarious $(23 \%)$, and primary $(23 \%)$ components. Of the species listed by Reséndez-Medina and Salvadores (2000) and Castillo-Domínguez et al. 2011, the absence in this study of the pejelagarto Atractosteus tropicus Gill, 1863, the snooks Centropomus parallelus Poey, 1860 and C. undecimalis (Bloch, 1792), the jaguar capote Parachromis managuensis (Günther, 1867) and the grass carp Ctenopharyngodon idella (Valenciennes, 1844) are noteworthy. The pejelagarto and the snooks are commercial species with a high gastronomic value in the region (Espinosa-Pérez and Daza-Zepeda 2005). The jaguar capote and grass carp were introduced, the first to help local fisheries and the second for the biological control of invasive plants. At present, both species, are widely distributed in limnetic ecosystems of Mexico (Vera-Herrera et al. 1980, Espinosa-Pérez and Daza-Zepeda 2005)

In coastal wetlands, SM, MV and CWD are considered habitats with a high heterogeneity and structural complexity (Everet and Ruiz 1993, Rozas and Minello 2006, Sánchez et al. 2007, Montalvo-Urgel et al. 2010, Rozas and Minello 2010), that are important in the protection, feeding and reproduction of species (Minello and Zimmerman 1991, Pelicice and Agostinho 2006, Rozas and Minello 2006, Cetra and Petrere 2007, Genkai-Kato 2007). The smallest number of species was recorded for CWD and the greatest for USS, similar to the number of species collected in the other two structured habitats, MV and SM (Table 2). The low number of fish species (Paraneetroplus synspilus, Dormitator maculatus, Eleotris amblyopsis, and Ctenogobius claytonii) collected from CWD may be an underestimation caused by the manual sampling. Of these four species, the eleotrids D. maculatus and E. amblyopsis, and the cichlid P. synspilus were mainly collected from $\mathrm{MV}$, whereas the gobiid C. claytonii was found mainly in CWD (Table 2). Both eleotrids were absent in the previous studies of the Grijalva-Usumacinta Division (Chávez et al. 1989, Reséndez-Medina and Salvadores 2000, 
Castillo-Domínguez et al. 2011). The two eleotrids and the gobiid are omnivores that ocasionaly feed on insect larvae, while $P$. synspilus is a herbivore, all recorded frequently in vegetation (Schmitter-Soto 1998). Juveniles of $D$. maculatus are common in flooded areas covered by emergent rooted vegetation at the start of the maximum flooding season. The marked difference between this catalogue and the three previous studies cited before for the GrijalvaUsumacinta Division has been the increase to five poeciliid species (Belonesox belizanus, Gambusia sexradiata, $G$. yucatana, Heterandria bimaculata, Heterophallus aff. rachovii, and Xiphophorus maculatus). This may also be related to the inclusion of structured habitats in the sampling, as the livebearers were collected mainly from MV where they feed mainly on insect larvae (Schmitter-Soto 1998, Miller et al. 2005).

In spite of the highest number of species collected in USS throughout this study, the different records for the BRPC corresponded to the structured habitats, which were not sampled systematically by Reséndez-Medina and Salvadores (2000). Therefore, the addition of species to the BRPC list is attributed to sampling in structured habitats and to the variety of sampling gears used, rather than to the recent taxonomic re-assignation of some fish species. In this context, the greater number of species and the similarity between the USS and the other two structured habitats respond to the fact that this unstructured habitat represents approximately $99 \%$ of the available substrate in the BRPC. Of special attention are the number of species and the similarity between the habitats of $\mathrm{SM}$ and MV, as the first one occupies less than $1 \%$ of the substrate in the Reserve and the second covers approximately $83 \%$ of the margins of the aquatic ecosystems in the BRPC. This contrast in cover area lays emphasis on the importance of generating programmes for the rehabilitation of submerged macrophytes (Ruíz-Carrera and Sánchez 2008) and marginal vegetation, which may take place together with the development of monitoring programmes in this tropical wetland.

\section{ACKNOWLEDGEMENTS}

The authors thank Dr. ML Lozano-Vilano and Dr. ME García-Ramírez, FCB-UANL, for help in the identification of some species, and biologists M Cruz-Ascencio, $G$ Lara de la Cruz, JC Domínguez, and L Jiménez for help in the field. Sampling was supported by SIPA-PEMEX and FIRBCENTLA.

\section{REFERENCES}

Anonymous 2007. Ley General de Pesca y Acuacultura Sustentables. Diario Oficial de la Federación. DOF 24-07-2007: 1-51 pp.

Anonymous 2010a. Norma Oficial Mexicana NOM-059-SEMARNAT-2010 Protección ambiental-Especies nativas de México de flora y fauna silvestres-Categorías de riesgo y especificaciones para su inclusión, exclusión o cambio-Lista de especies en riesgo. Diario Oficial de la Federación. 30 de diciembre de 2010. SEMARNAT. Segunda sección. México.
Anonymous 2010b. Carta Nacional Pesquera. Secretaría de Agricultura, Ganadería, Desarrollo Rural, Pesca y Alimentación. Cuarta sección, Diario Oficial de la Federación, 2 diciembre 2010. México.

Anonymous 2010c. Comisión Nacional de areas Naturales Protegidas. SEMARNAP: México.

http://www.conanp.gob.mx [Accessed on 24 June 2011.]

Anonymous 2011a. IUCN Red list of threatened species. Version 2011.1. http://www.iucnredlist.org [Accessed on 16 June 2011.]

Anonymous 2011b. The list of Wetlands of International Importance. The Ramsar Convention on Wetlands. http://www.ramsar.org/pdf/sitelist.pdf [Accessed on 24 Aug 2011.]

Austin H. 1971. A survey of the ichthyofauna of the mangroves of western Puerto Rico during December, 1967-August, 1968. Caribbean Journal of Science 11 (1-2): 27-39.

Avilés-Torres S., Schmitter-Soto J.J., Barrientos-Medina R.C. 2001. Patrones espaciales de la riqueza de peces en lagunas costeras del sur de Quintana Roo, México. Hidrobiológica 11 (2): 141-148.

Ayala-Pérez L.A., Avilés-Alatriste O.A., Rojas-Galaviz J.L. 1998. Estructura de la comunicad de peces en el sistema Candelaria-Panlau, Campeche, México. Revista de Biología Tropical 46 (3): 763-774.

Ayala-Pérez L.A., Ramos M.J., Flores H.D. 2003. La comunidad de peces de la Laguna de Términos: estructura actual comparada. Revista de Biología Tropical 51 (3-4): 783-794.

Bockmann F.A., Guazzelli G.M. 2003. Family Heptapteridae (Heptapterids). Pp. 406-431. In: Reis R.E., Kullander S.O., Ferraris C.J.jr. (eds.) Checklist of the freshwater fishes of South and Central America. EDIPUCRS, Porto Alegre.

Brower J.E., Zar J.H. 1981. Field and laboratory methods for general Ecology, WMC Brown, Dubuque.

Caballero-Vázquez J.A., Gamboa-Pérez H., Schmitter-Soto J.J. 2005. Composition and spatio-temporal variation of the fish community in the Chacmochuch Lagoon system, Quintana Roo, Mexico. Hidrobiológica 15 (2): 215-225.

Carpenter K.E. (ed.) 2002a. The living marine resources of the western central Atlantic. Vol. 2: Bony fishes. Part 1. (Acipenseridae to Grammatidae). FAO Species Identification Guide for Fishery Purposes and American Society of Ichthyologist and Herpetologists Special Publication No. 5. FAO, Rome.

Carpenter K.E. (ed.) 2002b. The living marine resources of the western central Atlantic. Vol. 2: Bony fishes. Part 2. (Ophistognathidae to Molidae), sea turtles and marine mammals. FAO Species Identification Guide for Fishery Purposes and American Society of Ichthyologist and Herpetologists Special Publication No. 5. FAO, Rome.

Castillo-Domínguez A., Barba M.E., Navarrete A.J., Rodiles Hernández R., Jiménez B.M.L. 2011. Ictiofauna de los humedales del río San Pedro, Balancán, Tabasco, México. 59 (2): 693-708.

Castro-Aguirre J.L., Espinosa-Pérez H., Schmitter-Soto J.J. 1999. Ictiofauna estuarino-lagunar y vicaria de México. Limusa-Noriega, Ciudad de México.

Cetra M., Petrere M.jr. 2007. Associations between fish assemblages and riparian vegetation in the Corumbataí River Basin (SP). Brazilian Journal of Biology 67 (2): 191-195. 
Chakrabarty P. 2007. A morphological phylogenetic analysis of middle American cichlids with special emphasis on the section 'Nandopsis' sensu Regan. Miscellaneous Publications, Museum of Zoology, University of Michigan (198): 1-31.

Chávez M., Mattheeuws A., Pérez M. 1989. Biología de los peces de San Pedro en vista de determinar su potencial para la piscicultura. INIREB-FUCID, Xalapa.

Chávez-López R., Rocha R.A., Ramírez R.A. 2005. Cambios en los ensamblajes de peces del sistema lagunar de Alvarado (SLA), Veracruz, México. Revista Digital Universitaria 6 (8): $1-19$.

Contreras-Balderas S., Almada-Villela P., Lozano-Vilano M.L., García-Ramírez M.E. 2003. Freshwater fish at risk or extinct in Mexico. A checklist and review. Reviews in Fish Biology and Fisheries 12 (2-3): 241-251.

DOI: $10.1023 / \mathrm{A}: 1025053001155$

Corona G.A. 2005. Diversidad íctica en ríos de la vertiente del Pacífico de Chiapas. Revista Digital Universitaria 6 (8): 1-12.

Darrin H.C., García de León F.J., Sánchez J.Y., Hendrickson D.A., Near T.J. 2004. Temporal diversification of Mesoamerican cichlid fishes across a major biogeographic boundary. Molecular Phylogenetics and Evolutions 321: 754-764. DOI: 10.1016/j.ympev.2003.08.024

de la Vega M. 2003. Situación de los peces dulceacuícolas de México. Ciencias 72: 20-30.

Dudgeon D., Arthington A.H., Gessner M.O., Kawabata Z.I., Knowler D.J., Lévêque C., Naiman R.J., Prieur-Richard A.H., Soto D., Stiassny L.J., Sullivan C.A. 2006. Freshwater biodiversity: importance, threats, status and conservation challenges. Biological Review 81 (2): 163-182. DOI: $10.1017 / \mathrm{S} 1464793105006950$

Espinosa-Pérez H., Daza-Zepeda A. 2005. Peces. Pp. 225-240. In: Bueno J., Álvarez F., Santiago S. (eds.) Biodiversidad del estado de Tabasco. CONABIO-UNAM, Ciudad de México.

Espinosa-Pérez H., Fuentes P., Gaspar-Dillanes M.T., Arenas V. 1998. Notas acerca de la ictiofauna mexicana. Pp. 227-249. In: Ramamoorthy T.P., Bye R., Lot A., Fa J. (eds.) Diversidad Biológica de México: Orígenes y Distribución, Editorial, Ciudad de México.

Espinosa-Pérez H., Huidobro L., Flores C., Fuentes-Mata P., Funes R. 2008. Diversidad de peces mexicanos. Manuscrito para el Segundo Estudio de País. CONABIO, Ciudad de México.

Everett R.A., Ruiz G.M. 1993. Coarse woody debris as a refuge from predation in aquatic communities. An experimental test. Oecologia 93 (4): 475-486.

Ferraris C.J. jr. 2007. Checklist of catfishes, recent and fossil (Osteichthyes: Siluriformes), and catalogue of siluriform primary types. Zootaxa 2007 (1418): 1-628.

Froese R., Pauly D. (eds.) 2011. FishBase. [version 02/2011] http://www.fishbase.org

Gamboa-Pérez H.C. 1992. Peces continentales de Quintana Roo. Pp. 304-360. In: Navarro D., Suárez-Morales E. (eds.) Diversidad Biológica de la Reserva de la Biosfera de Sian Ka'an, Quintana Roo. CIQRO/SEDESOL, Chetumal.

Gaspar-Dillanes M.T. 1996. Aportación al conocimiento de la ictiofauna de la Selva Lacandona, Chiapas. Zoología Informa 33: 41-54.
Genkai-Kato M. 2007. Macrophyte refuges, prey behavior and trophic interactions: consequences for lake water clarity. Ecology Letters 10 (2): 105-114. DOI: 10.1111/j.1461-0248.2006.01000.x

Gilmore G.R. 1995. Environmental and biogeographic factors influencing ichthyofaunal diversity: Indian River Lagoon. Bulletin Marine Science 57 (1): 153-170.

Guadarrama M.A., Ortiz G. 2000. Análisis de la flora de la Reserva de la Biosfera Pantanos de Centla, Tabasco. Universidad y Ciencia 15 (30): 67-104.

Guerra V., Ochoa S. 2008. Evaluación del plan de manejo de la Reserva de la Biosfera Pantanos de Centla en Tabasco, México. Universidad y Ciencia 24 (2): 135-146.

Heck K.L., Crowder L.B. 1991. Habitat structure and predatorprey interactions in vegetated aquatic systems. Pp. 281-299. In: Bell S.S., McCoy E.D., Mushinsky H.R. (eds.) Habitat structure: The physical arrangement of objects in space. Population and Community Biology Series. Chapman and Hall, London.

Hines A.H., Ruiz G.M. 1995. Temporal variation in juvenile blue crab mortality: nearshore shallows and cannibalism in Chesapeake Bay. Bulletin Marine Science 57 (3): 884-901.

Jorgensen P., Ibarra-Obando S.E., Carriquiry JD. 2007. Top-down and bottom-up stabilizing mechanisms in eelgrass meadows differentially affected by coastal upwelling. Marine Ecology Progress Series 333: 81-93.

López-Fernández H., Winemiller C.K.O, Honeycutt R.L. 2010. Multilocus phylogeny and rapid radiations in neotropical cichlid fishes (Perciformes: Cichlidae: Cichlinae). Molecular Phylogenetics and Evolution 55 (3): 1070-1086. DOI: $10.1016 /$ j.ympev.2010.02.020

López-López E., Sedeño-Díaz J.E., López R.F., Trujillo-Jiménez P. 2009. Spatial and seasonal distribution patterns of fish assemblages in the Río Champotón, southeastern Mexico. Reviews in Fish Biology and Fisheries 19 (2): 127-142. DOI: 10.1007/s11160-008-9093-y

Lozano-Vilano M.L., Contreras-Balderas S. 1987. Lista zoogeográfica y ecológica de la ictiofauna continental de Chiapas, México. The Southwestern Naturalist 32 (2): 223-236.

Lozano-Vilano M.L., García-Ramírez M.E., Contreras-Balderas S., Ramírez-Martínez C. 2007. Diversity and conservation status of the ichthyofauna of the Río Lacantún basin in the Biosphere Reserve Montes Azules, Chiapas, México. Zootaxa 2007 (1410): 43-53

Marceniuk A.P., Betancur-R. R. 2008. Revision of the species of the genus Cathorops (Siluriformes: Ariidae) from Mesoamerica and the Central American Caribbean, with description of three new species. Neotropical Ichthyology 6 (1): 25-44. DOI: 10.1590/S1679-62252008000100004

Marceniuk A.P., Menezes N.A. 2007. Systematics of the family Ariidae (Ostariophysi, Siluriformes), with a redefinition of the genera. Zootaxa 2007 (1416): 1-126.

McEachran J.D., Fechhelm J.D. 2005. Fishes of the Gulf of Mexico. University of Texas Press, Austin, TX.

McMahan C.D., Geheber A.D., Piller K.R. 2010. Molecular systematics of the enigmatic middle American genus Vieja (Teleostei: Cichlidae). Molecular Phylogenetics and Evolution 57 (3): 1293-1300. DOI: 10.1016/j.ympev.2010.09.005 
Miller R., Minckley W.L., Norris S.T. 2005. Freshwater fishes of México. The University of Chicago Press. Chicago, IL.

Minckley W.L., Miller R.R., Barbour C.D., Schmitter-Soto J.J., Norris S.M. 2005. Historical Ichthyogeography. Pp. 24-47. In: Miller R., Minckley W.L., Norris S.T. (eds.) Freshwater fishes of Mexico. The University of Chicago Press. Chicago, IL.

Minello T.J., Zimmerman R.J. 1991. The role of estuarine habitats in regulating growth and survival of juvenile penaeid shrimp. Pp. 1-16. In: Deloach P.F., Dougherty W.J., Davidson M.A. (eds.) Frontiers of shrimp research. Development in aquaculture and fisheries. Elsevier, Amsterdam.

Moksnes P.O., Lipcius R.N., Pihl L., van Montfrans J. 1997. Cannibal-prey dynamics in young juveniles and postlarvae of the blue crab. Journal of Experimental Marine Biology and Ecology 215 (2): 157-187. DOI:10.1016/S0022-0981(97)00052-X

Montalvo-Urgel H., Sánchez A.J., Florido R., Macossay-Cortez A. 2010. Lista de crustáceos distribuidos en troncos hundidos en el humedal tropical Pantanos de Centla, al sur del Golfo de México. Revista Mexicana de Biodiversidad 81 (S): S121-S131.

Morales D.A. 2003. Biología, cultivo y comercialización de la tilapia. AGT Editor, Ciudad de México.

Nelson J.S. 2006. Fishes of the World. Wiley, New York.

Nelson J.S., Crossman E.J., Espinosa-Pérez H., Findley L.T., Gilbert C.R., Lea R.N., Williams J.D. 2004. Common and scientific names of fishes from the United States, Canada and Mexico. American Fisheries Society, Bethesda, MD.

Oswald-Spring U. 2008. Agua, cultura, conflictos y desarrollo sustentable: Los retos del Instituto del Agua. Pp. VII-XIV. In: Sánchez A.J., Fernández J.B. (eds) Diseño del Instituto del Agua de Tabasco. Manejo integrado de los Recursos Hídricos. Colección José N. Rovirosa. Universidad Juárez Autónoma de Tabasco, México.

Parra H.B.J. 1984. Análisis del contenido estomacal y hábitos alimenticios de la camiguana Anchoa parva (Meek \& Hildebrand, 1923) (Pisces: Engraulidae) del golfo de Cariaco, Edo. Sucre, Venezuela. Boletín Instituto Oceanografico Venezuela 23 (1-2): 3-13.

Pelicice F.M., Agostinho A.A. 2006. Feeding ecology of fishes associated with Egeria spp. patches in a tropical reservoir, Brazil. Ecology of Freshwater Fish 15: 10-19.

DOI: 10.1111/j.1600-0633.2005.00121.x

Pérez-León S., Schmitter-Soto J.J. 2007. Distribución y taxonomía del género Gambusia (Teleostei: Poeciliidae) en el norte y oriente de la Península de Yucatán, México. Universidad y Ciencia 23 (2): 167-171.

Rauchenberger M. 1989. Systematics and Biogeography of the genus Gambusia (Cyprinodontiformes: Poecilidae). American Museum of Natural History, New York.

Renfro W.C. 1962. Small beam net for sampling postlarval shrimp. US Fish and Wildlife Service C 161: 86-87.

Reséndez-Medina A. 1980. Peces colectados en el sistema lagunar El Carmen-Machona-Redonda, Tabasco, México. Anales del Instituto de Biología, Universidad Nacional Autónoma de México, Serie Zoología 51 (1): 477-504.

Reséndez-Medina A. 1981. Estudio de los peces de la Laguna de Términos, Campeche, México. Biótica 6 (3-4): 240-430.
Reséndez-Medina A., Kobelkowsky-Díaz A. 1991. Ictiofauna de los sistemas lagunares costeros del Golfo de México. Universidad y Ciencia 8 (15): 91-108.

Reséndez-Medina A., Salvadores M.L. 2000. Peces de la Reserva de la Biosfera "Pantanos de Centla". Resultados preliminares. Universidad y Ciencia 15 (30): 141-147.

Revenga C., Campbell I., Abell R., de Villiers P., Bryer M. 2005. Prospects for monitoring freshwater ecosystems towards the 2010 targets. Philosophical Transactions of the Royal Society B 360 (1454): 397-413. DOI: 10.1098/rstb.2004.1595

Rodiles-Hernández R., González-Díaz A.A., Chan-Sala C. 2005. Lista de peces continentales de Chiapas, México. Hidrobiológica 15 (2): 245-253.

Rozas L.P., Minello T.J. 2006. Nekton use of Vallisneria americana Michx. (wild celery) beds and adjacent habitats in coastal Lousiana. Estuaries and Coasts 29 (2): 297-310.

Rozas L.P., Minello T.J. 2010. Nekton density patterns in tidal ponds and adjacent wetlands related to pond size and salinity. Estuaries and Coasts 33 (3): 652-667. DOI: $10.1007 / \mathrm{s} 12237-009-9258-5$

Ruíz-Carrera V., Sánchez A.J. 2008. Development of in vitro culture model for Vallisneria americana Michx. Universidad y Ciencia 24 (3): 205-218.

Sammons S.M., Maceina M.J. 2006. Changes in diet and food consumption of largemouth bass following large-scale hydrilla reduction in Lake Seminole, Georgia. Hydrobiologia 560 (1): 109-120. DOI: 10.1007/s10750-005-1163-8

Sánchez A.J., Raz-Guzman A. 1997. Distribution patterns of tropical estuarine brachyuran crabs in the Gulf of Mexico. Journal of Crustacean Biology 17: 609-620.

Sánchez A.J., Salcedo M.A., Florido R., Armenta A., Rodriguez C., Galindo A., Moguel E. 2007. Pantanos de Centla, un humedal costero tropical. Pp. 225-240. In: de la Lanza G., Hernández S. (eds.) Las aguas interiores de México: conceptos y casos. AGT EDITOR, S.A. México.

Sánchez C., Rueda M. 1999. Variación de la diversidad y abundancia de especies ícticas dominantes en el delta del Río Magdalena, Colombia. Revista de Biología Tropical 47 (4): 1067-1079.

Schmitter-Soto J.J. 1998. Catálogo de los peces continentales de Quintana Roo. El Colegio de la Frontera Sur, San Cristóbal de las Casas.

Schmitter-Soto J.J. 2006. Integridad biótica y biodiversidad acuática: El caso de la tilapia africana en Quintana Roo. Ecofronteras 28: 22-26.

Schmitter-Soto J.J. 2007. A systematic revision of the genus Archocentrus (Perciformes: Cichlidae), with the description of two new genera and six new species. Zootaxa 2007 (1603): $1-78$.

Snoeks J., Laleye P., MacBeath T. 2007. Parachromis friedrichsthalii. In: IUCN 2011. IUCN red list of threatened species. [Version 2011.1.] www.iucnredlist.org

Soria-Barreto M., Rodiles-Hernández R. 2008. Spatial distribution of cichlids in Tzendales River, Biosphere Reserve Montes Azules, Chiapas, Mexico. Environmental Biology of Fishes 83 (4): 459-469. DOI: 10.1007/s10641-008-9368-0

Velázquez V.G. 1994. Los recursos hidráulicos del Estado de Tabasco. UJAT, Villahermosa. 
Vera-Herrera F.R., Rojas-Galaviz J.L., Medina J.A., Flores R.D. 1980. Control biológico del lirio acuático Eichhornia crassipes mediante la carpa herbívora Ctenopharyngodon idella (Pisces: Cyprinidae) en estanques controlados. Anales del Centro de Ciencias del Mar y Limnología, Universidad Nacional Autónoma de México 7 (2): 1-302.

Warfe D.M., Barmuta L.A. 2006. Habitat structural complexity mediates food web dynamics in a freshwater macrophyte community. Oecologia 150 (1): 141-154.

DOI: $10.1007 / \mathrm{s} 00442-006-0505-1$

Warren M.L. jr., Burr B.M., Walsh S.J., Bart H.L. jr., Cashner R.C., Etnier D.A., Freeman B.J., Kuhajda B.R., Mayden R.L., Robison H.W., Ross S.T., Starnes W.C. 2000. Diversity, distribution, and conservation status of the native freshwater fishes of the southern United States. Fisheries 25 (10): 7-31.

Wetzel R.G. 2001. Limnology: Lake and river ecosystems. Academic Press, San Diego.

Willink P.W., Barrientos C., Kihn H.A., Chernoff B. 2000. An Ichthyological survey of Laguna del Tigre National
Park, Peten, Guatemala. Pp. 41-48. In: Bestelmeyer B.T., Alonso L.E., (eds.) A biological assessment of laguna del Tigre National Park, Petén, Guatemala. Conservation International, Washington, DC.

Yamazaki Y., Haramoto S., Fukasawa T. 2006. Habitat uses of freshwater fishes on the scale of reach system provided in small streams. Environmental Biology of Fishes 75: 333-341. DOI: 10.1007/s10641-006-0032-2

Yáñez-Arancibia A., Lara Domínguez A.L., Gil P., ÁlvarezGuillen H. 1988. Evaluación ecológica de las comunidades de peces en la Laguna de Términos y la sonda de Campeche. Pp. 323-256. In: Yáñez-Arancibia A., Day J.W., (eds.) Ecología de los Ecosistemas Costeros en el Sur del Golfo de México: La región de la Laguna de Términos. Inst. Cienc. del Mar y Limnol. UNAM COSAT. Ecol. Inst. LSU. Editorial Universitaria, México.

Received: 24 May 2011

Accepted: 28 September 2011 Published electronically: 30 September 2011 